\title{
Total Ore Processing Integration and Management
}

\author{
3rd Quarterly Technical Progress Report \\ 01 January - 31 March 2004
}

\author{
written by \\ Leslie Gertsch and Richard Gertsch
}

submitted

30 April 2004

DOE Award Number DE-FC26-03NT41785

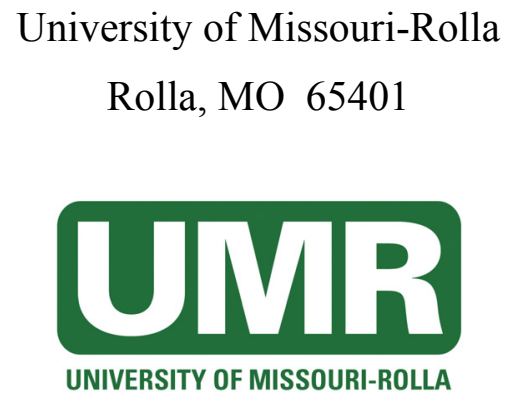




\section{Disclaimer}

This report was prepared as an account of work sponsored by an agency of the United States Government. Neither the United States Government nor any agency thereof, nor any of their employees, makes any warranty, express or implied, or assumes any legal liability or responsibility for the accuracy, completeness, or usefulness of any information, apparatus, product, or process disclosed, or represents that its use would not infringe privately owned rights. Reference herein to any specific commercial product, process, or service by trade name, trademark, manufacturer, or otherwise does not necessarily constitute or imply its endorsement, recommendation, or favoring by the United States Government or any agency thereof. The views and opinions of authors expressed herein do not necessarily state or reflect those of the United States Government or any agency thereof. 


\section{Abstract}

This report outlines the technical progress achieved for project DE-FC26-03NT41785 (Total Ore Processing Integration and Management) during the period 01 January through 31 March of 2004. 


\section{Table of Contents}

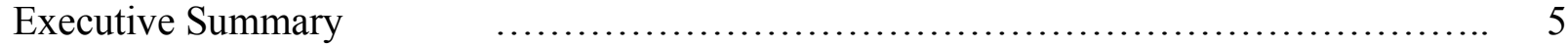

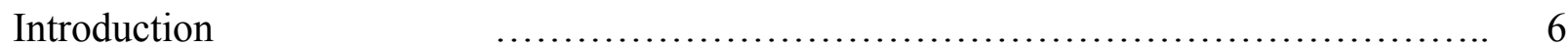

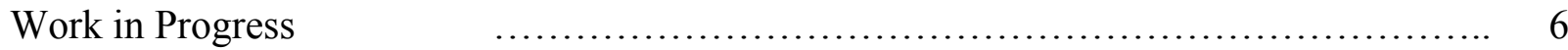

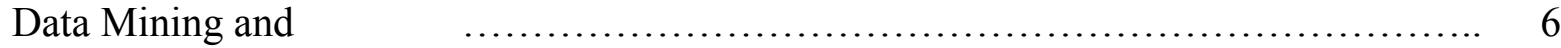

Analysis, Minntac Mine

Data Mining, Hibtac $\quad$......................................................... 8

Mine

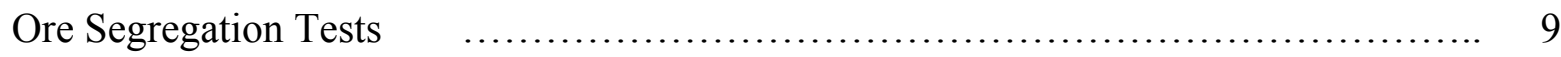

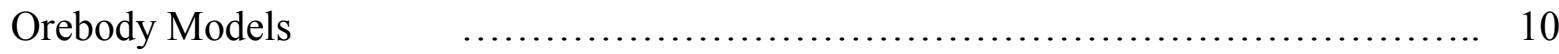

Correlation between $\quad$.................................................... 10

Minntac Mine and

Hibtac Mine

Future Work

Data Mining

Orebody Models

Ore Segregation Tests

Appendix: Data Summary from Minntac Mine Ore Segregation Test \#2

Appendix: Charts from

Minntac Mine Ore

Segregation Test \#2

\section{List of Graphical Materials}

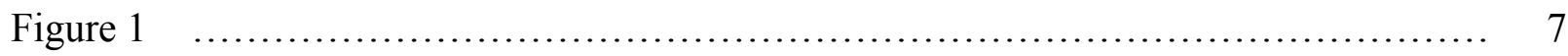

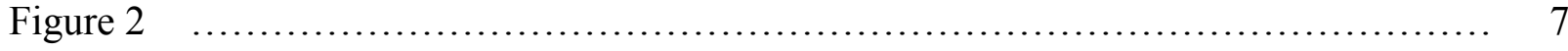

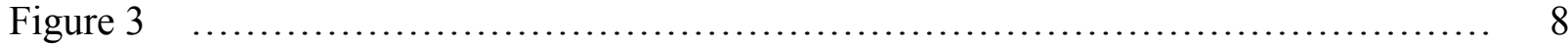

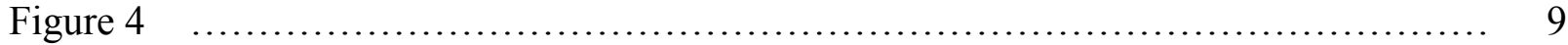

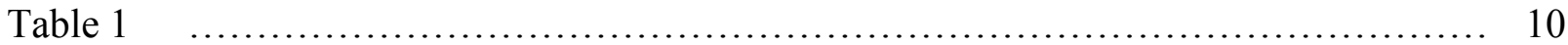




\section{Executive Summary}

\section{Work in Progress: Data Mining and Analysis, Minntac Mine}

Several approaches are being evaluated for efficient description of the ore grindability at Minntac Mine. Hibtac Mine uses a process that is fundamentally similar, but differs in details of its execution. The grindability data has been fit with a straight line $(Y=m X+b)$ which, though simple to calculate, does not completely reflect the curve visible in the data points. Yet it is apparent that the exponential mathematical function does not completely describe the physical processes at work, either. The silica liberation data, however, is fairly well approximated by an exponential curve with asymptote fixed at zero. The goal is to produce a predictive tool that is easy to use and communicate between mine and mill.

\section{Work in Progress: Data Mining, Hibtac Mine}

Data mining is at an earlier stage for the Hibtac Mine; consequently, the extent of the prestudy data is still being determined.

\section{Work in Progress: Ore Segregation Tests}

Basic hypothesis testing has been partially completed for the second ore segregation test performed at Minntac Mine. The procedure followed is described in Quarterly Technical Progress Report \#2.

\section{Work in Progress: Orebody Models}

The assay, grindability, and liberation data from the exploration cores at Minntac Mine have been composited into ore blocks that correspond to the average size of the working benches. These composited values were plotted in histograms and cumulative curves to enhance visual evaluation of their distinguishing characteristics. Note that the HIS (high silica) and IBC (interbedded chert) designations together correspond to the Lower Slate layer. These designations reflect qualitative differences in crushing and grinding performance observed by U.S. Steel personnel.

\section{Work in Progress: Correlation between Minntac Mine and Hibtac Mine}

The two mines operate in the same geological formations, but over the years they have developed different approaches to characterizing the layers.

\section{Future Work: Data Mining}

Previously collected data at both Hibtac and Minntac Mines will continue to be explored and analyzed, supplemented by discussions with mine and laboratory personnel.

\section{Future Work: Orebody Models}

The Minntac Mine model will continue to be refined and compared to measured data. A model of the Hibtac Mine will be started sometime during the next two quarters.

\section{Future Work: Ore Segregation Tests}

More sophisticated statistical analysis is planned for the data produced during both ore segregation tests at Minntac Mine. 


\section{Introduction}

This third quarterly report discusses the activities of the project team during the period 1 January through 31 March 2004.

\section{Work in Progress}

\section{Data Mining and Analysis, Minntac Mine}

The results of previous research conducted by Coleraine Research Laboratories were obtained, courtesy of Coleraine and Pete Niles. This includes data of many different types. Indepth study of this document is underway.

Several approaches are being evaluated for efficient description of the grindability curve as it is currently determined at Minntac Mine. Hibtac Mine uses a process that is fundamentally similar, but differs in details of its execution.

In the Mesabi Range, the magnetic iron is contained within magnetite, which occurs in taconite as granules that average less than $0.1 \mathrm{~mm}$ in diameter. Even when they clump to form larger grains, the actual mineral crystals remain much smaller than the clump size. Therefore, the required particle size for effective separation of ore from waste is extremely fine; Minntac Mine uses the coarsest grind (85\% passing 270 mesh, or 53 microns max. size), while Hibtac Mine grinds to $80 \%$ passing 325 mesh (44 microns). Both mines follow this energy-intensive step with several stages of magnetic separation. Minntac Mine then applies hydrometallurgical (flotation) techniques to remove much of the silica that remains in the concentrate.

The grindability data in this example has been fit with a straight line $(Y=m X+b)$ which, though simple to calculate, does not completely reflect the curve visible in the data points. An exponential curve can be used instead $\left(Y=Y_{0}-C e^{-k X}\right)$, where $Y$ is the silica within the material produced by grinding to time $X ; Y_{0}$ is the curve's asymptote. Yet the results are not satisfying. As shown in Figure 1, forcing the asymptote to $Y=100 \%$, its correct physical value, results in curves noticeably less well-matched to the data points than letting the asymptote be fitted directly to the data with no constraints on its value. This latter approach yields curves that look more appropriate, but it gives unreasonably high fineness values (above 100\% passing 270 mesh) when extrapolated to grinding times longer than actually measured. It is apparent that the exponential mathematical function does not completely describe the physical processes at work.

The silica liberation data, however, is fairly well approximated in this example (Figure 2) by an exponential curve. The asymptote constant $Y_{0}$ is fixed at zero in this case.

Figure 3 illustrates one approach to combining grindability and silica liberation data, using a linear predictor for grindability and an exponential predictor for silica liberation. The success of the magnetic separation and flotation stages of processing depends on accurate characterization of the energy required to grind the ore to the necessary fineness, as well as its relationships to liberation of silica and magnetic iron. The goal is to produce a tool that is easy to use and communicate between mine and mill. 


\section{Grindability Chart for Typical Sample: Descriptive Functions}

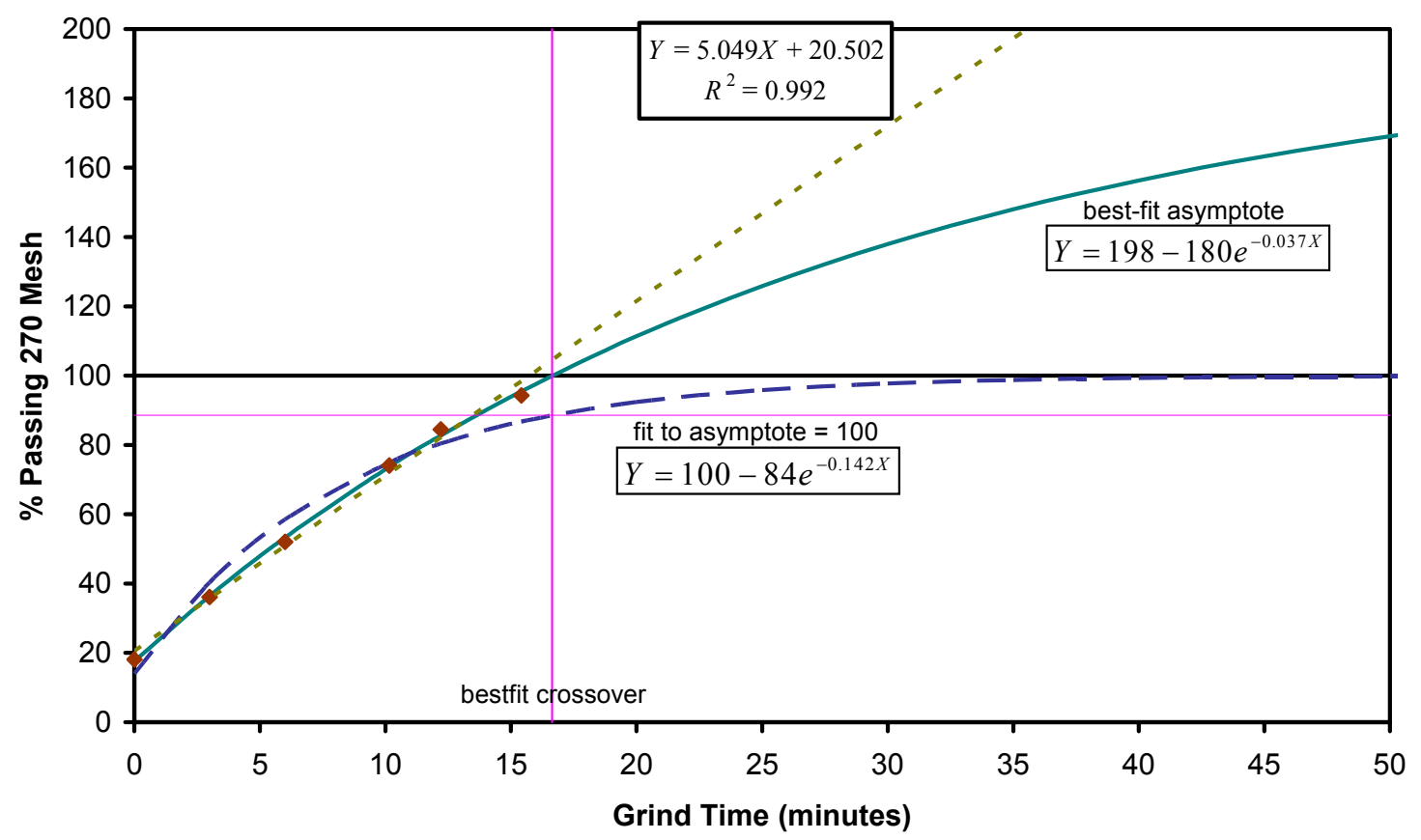

Figure 1. Some approaches to characterizing grindability data.

\section{Silica Liberation Chart for Typical Sample: Descriptive Functions}

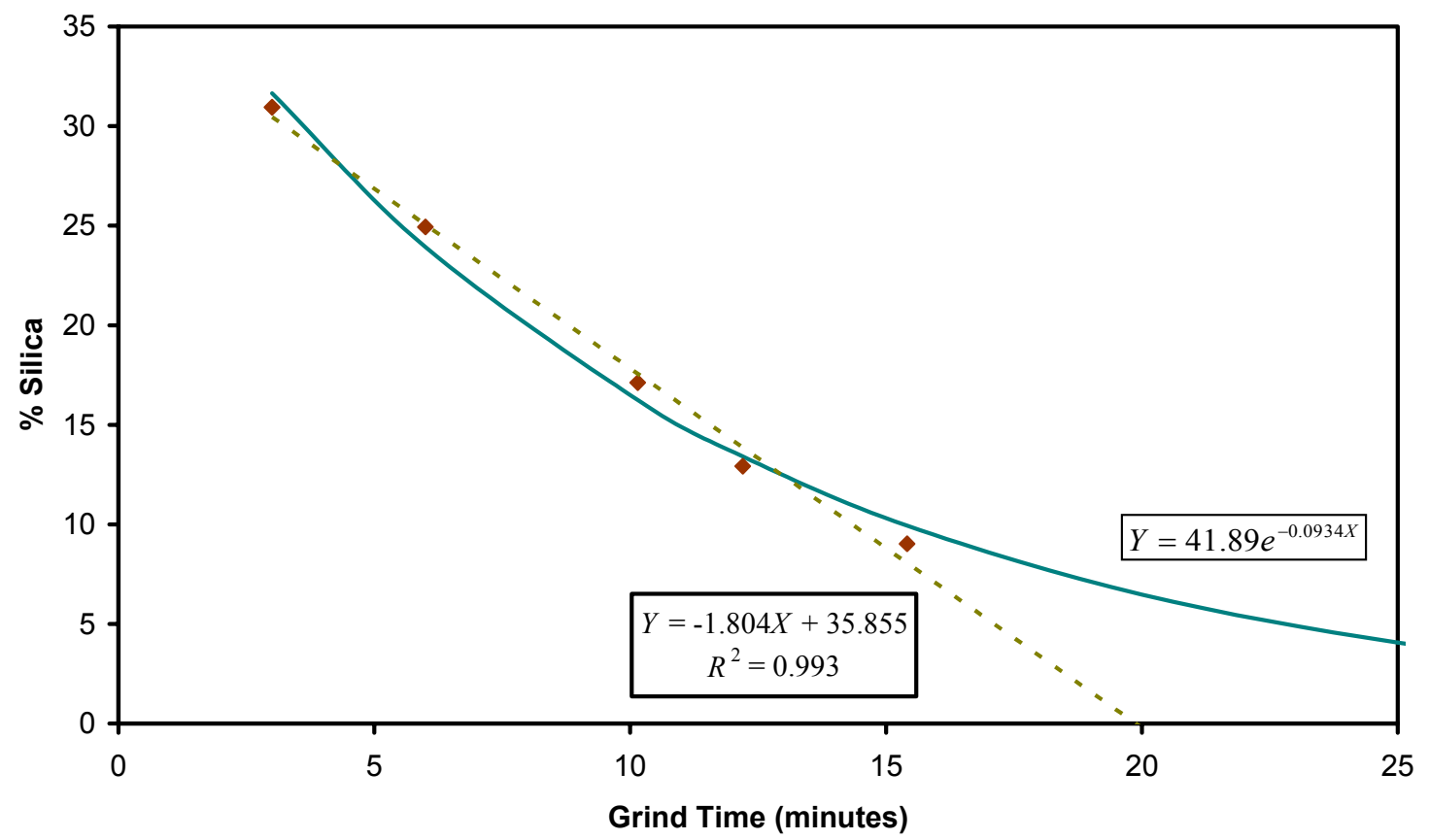

Figure 2. Some approaches to characterizing silica liberation data. 


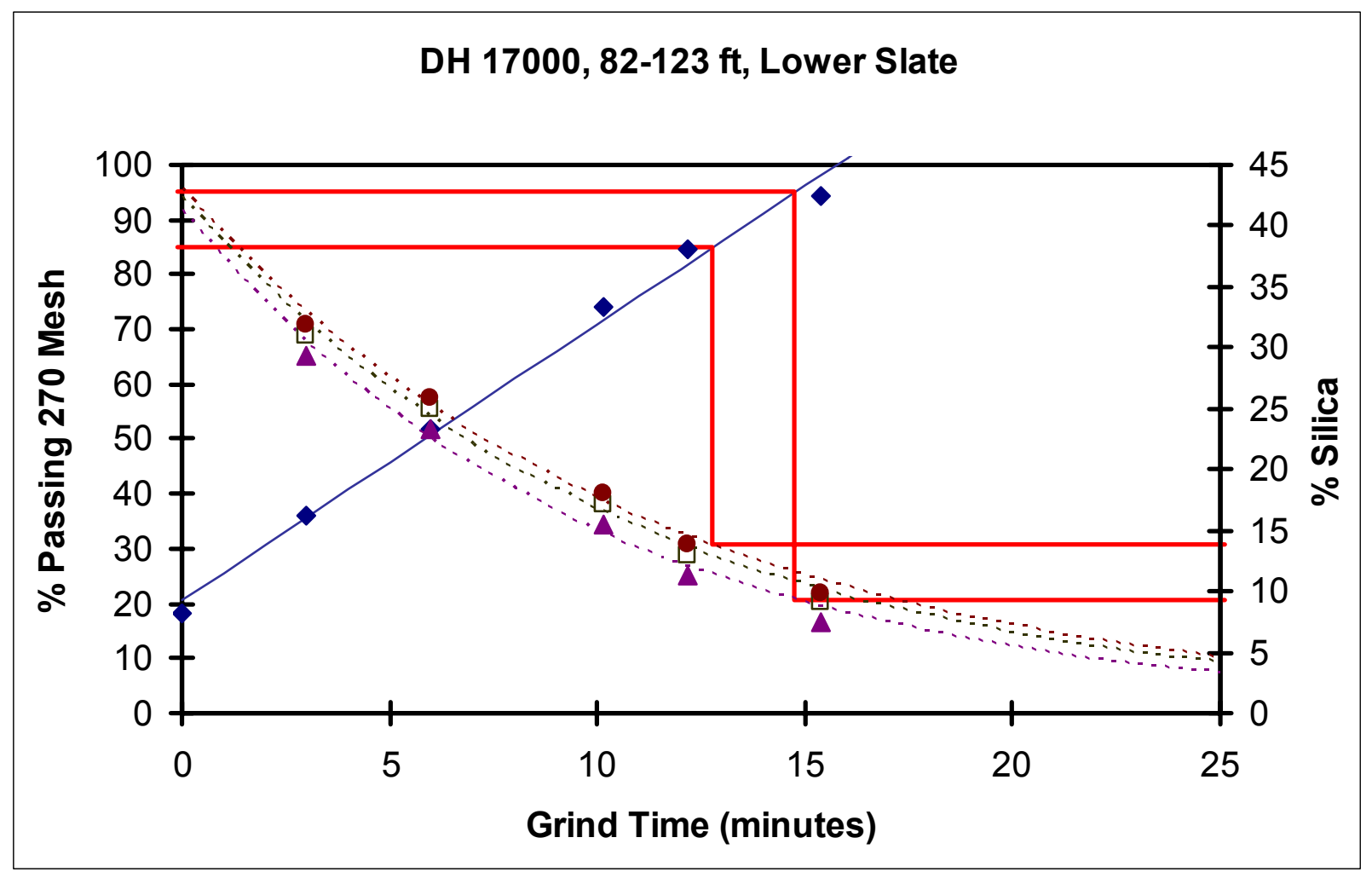

Figure 3. One method of combining grindability and silica liberation. The dashed lines are exponential predictors for silica liberation (measured separately for three subintervals). The solid blue line predicts the grindability, measured once for the full interval. The thick red lines indicate the amount of silica available at the standard particle fineness values of $85 \%$ and $95 \%$, from which A-factor is calculated.

It should be remembered that not all grindability and liberation data follow these patterns, and so may not be well-fit by these types of curves. Qualitative review of the available data shows several other patterns that will be addressed during the next quarter.

\section{Data Mining, Hibtac Mine}

Data mining is at an earlier stage for the Hibtac Mine; consequently, the extent of the prestudy data is still being determined. Figure 4 illustrates a preliminary graphical analysis of six months of muck size distribution data, compared with a liberation index calculated in terms of expected grinding mill power draw. This is the functional equivalent to the A-factor calculated by Minntac Mine. 

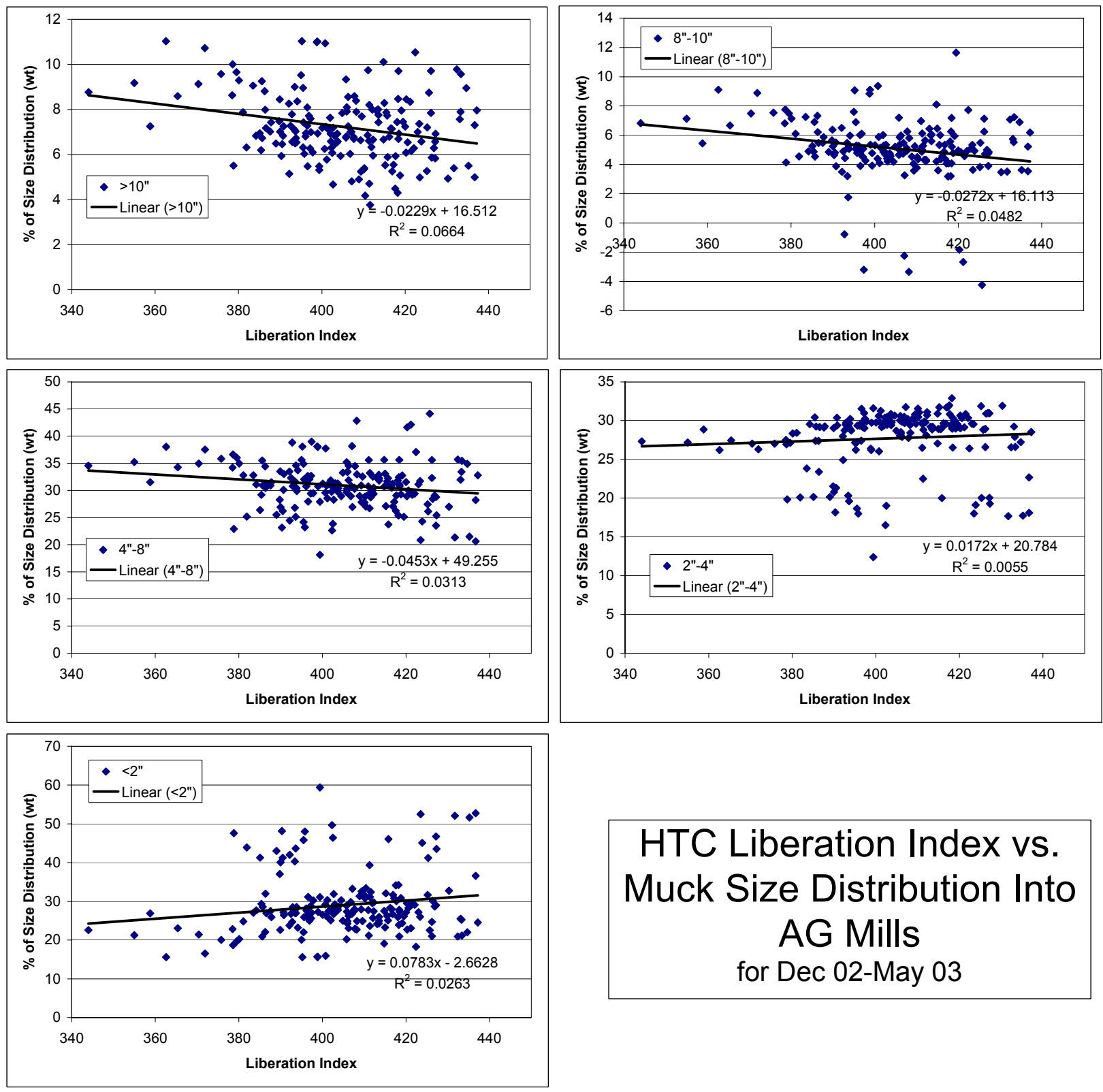

\begin{tabular}{|c|}
\hline HTC Liberation Index vs. \\
Muck Size Distribution Into \\
AG Mills \\
for Dec 02-May 03 \\
\hline
\end{tabular}

Figure 4.

\section{Ore Segregation Tests}

Basic hypothesis testing has been partially completed for the second ore segregation test performed at Minntac Mine. The procedure followed is described in Quarterly Technical Progress Report \#2. Partial results from test \#2, focused on the front end of the iron milling process, are shown in Table 1.

As was seen during test \#1, the high- and low-A factor lines showed different levels of silica, calcium oxide, and alumina. This time there were also differences in levels of magnesium and manganese. Again, it must be noted that the reported instrument errors were and extremely high for alumina readings, due possibly in the latter case to the levels measured being nearly below the detection limit of the inductively coupled plasma (ICP) equipment. 
Table 1. Some data comparisons between the low-A factor and the high-A factor ore processing lines before, during, and after the Minntac Mine ore segregation test \#2, at 90\% confidence level.

\begin{tabular}{|c|c|c|c|c|c|c|c|c|c|c|c|c|c|c|c|}
\hline \multirow{2}{*}{\multicolumn{3}{|c|}{$\begin{array}{r}\text { Crushers } 1 \& 2 \neq \text { Crushers } 3 \& 4 \\
\text { STATISTICALLY SIGNIFICANT }\end{array}$}} & \multicolumn{5}{|c|}{ Rod Mill $2 \neq$ Rod Mill 3} & \multicolumn{5}{|c|}{ Float Feed FLF $\neq$ Fload Feed FLD } & & & \\
\hline & & & & & & & & & & & & & & & \\
\hline DIFFERENCES (space) & crush - idle & $W+E$ & $\mathrm{Al}$ & $\mathrm{Ca}$ & $\mathrm{Mg}$ & $\mathrm{Mn}$ & $\mathrm{SiO}_{2}$ & $\mathrm{Al}$ & $\mathrm{Ca}$ & $\mathrm{Mg}$ & $\mathrm{Mn}$ & $\mathrm{SiO}_{2}$ & & & \\
\hline \begin{tabular}{|r|} 
Before Test \\
\end{tabular} & & & & & & & & $\mathbf{x}$ & $\mathbf{x}$ & $\mathrm{x}$ & $\mathbf{x}$ & $\mathrm{x}$ & & & \\
\hline During Test & & & $\mathbf{x}$ & & $\mathbf{x}$ & $\mathbf{x}$ & $\mathbf{x}$ & $\mathbf{x}$ & $\mathbf{x}$ & $\mathbf{x}$ & $\mathbf{x}$ & $\mathbf{x}$ & & & \\
\hline After Test & & & & & & & & $\mathbf{x}$ & $\mathbf{x}$ & $x$ & $\mathbf{x}$ & $\mathrm{x}$ & & & \\
\hline \multirow{3}{*}{$\begin{array}{l}\text { STATISTICALLY SIGNIF } \\
\text { DIFFERENCES (time) }\end{array}$} & \multicolumn{4}{|c|}{ Primary Crushers } & \multicolumn{5}{|c|}{ Rod Mill \#2 Feed (R2S) } & & & & & & \\
\hline & $1 \& 2$ & $1 \& 2$ & $3 \& 4$ & $3 \& 4$ & & & & & & & & & & & \\
\hline & crush - idle & $W+E$ & crush - idle & $W+E$ & $\mathrm{Al}$ & $\mathrm{Ca}$ & $\mathrm{Mg}$ & $\mathrm{Mn}$ & $\mathrm{SiO}_{2}$ & & & & & & \\
\hline \multirow{3}{*}{$\begin{array}{r}\text { Before } \neq \text { During } \\
\text { Before } \neq \text { After } \\
\text { During } \neq \text { After }\end{array}$} & $\mathbf{x}$ & $\mathbf{X}$ & & $\mathbf{x}$ & $\begin{array}{l}\mathbf{x} \\
\mathbf{x}\end{array}$ & $\mathbf{x}$ & $\begin{array}{l}x \\
x\end{array}$ & $\mathbf{X}$ & $\mathbf{X}$ & & & & & & \\
\hline & $\mathbf{x}$ & $x$ & $\mathbf{x}$ & & $\mathrm{x}$ & & & $x$ & $\mathrm{x}$ & & & & & & \\
\hline & \multicolumn{5}{|c|}{ Rod Mill \#3 Feed (R3S) } & \multicolumn{5}{|c|}{ Float Feed (FLF) } & & & & & \\
\hline \multicolumn{6}{|c|}{ STATISTICALLY SIGNIFICANT } & & & & & & & & & & \\
\hline DIFFERENCES (time) & $\mathrm{Al}$ & $\mathrm{Ca}$ & $\mathrm{Mg}$ & $\mathrm{Mn}$ & $\mathrm{SiO}_{2}$ & $\mathrm{Al}$ & $\mathrm{Ca}$ & $\mathrm{Mg}$ & $\mathrm{Mn}$ & $\mathrm{SiO}_{2}$ & & & & & \\
\hline Before $\neq$ During & $\bar{x}$ & \multirow{3}{*}{$\mathbf{x}$} & & & $\mathbf{X}$ & \multirow{3}{*}{\multicolumn{2}{|c|}{$\begin{array}{l}\mathbf{X} \\
\mathbf{X}\end{array}$}} & $\mathrm{X}$ & $\mathbf{X}$ & $\mathbf{X}$ & & & & & \\
\hline Before $\neq$ After & & & $\mathbf{x}$ & & $\mathbf{x}$ & & & $x$ & & $x$ & & & & & \\
\hline During $\neq$ After & $x$ & & $x$ & & $x$ & & & $\mathbf{x}$ & $x$ & & & & & & \\
\hline & \multicolumn{5}{|c|}{ Float Feed (FFD) } & \multicolumn{5}{|c|}{ Float Concentrate (FC3) } & \multicolumn{5}{|c|}{ Float Tails (FLT) } \\
\hline \multicolumn{6}{|c|}{ STATISTICALLY SIGNIFICANT } & & & & & & & & & & \\
\hline DIFFERENCES (time) & $\mathrm{Al}$ & $\mathrm{Ca}$ & $\mathrm{Mg}$ & $\mathrm{Mn}$ & $\mathrm{SiO}_{2}$ & Al & $\mathrm{Ca}$ & $\mathrm{Mg}$ & $\mathrm{Mn}$ & $\mathrm{SiO}_{2}$ & $\mathrm{Al}$ & $\mathrm{Ca}$ & $\mathrm{Mg}$ & $\mathrm{Mn}$ & $\mathrm{SiO}_{2}$ \\
\hline Before $\neq$ During & & $\mathbf{X}$ & $\mathbf{x}$ & $\mathbf{x}$ & $\mathbf{x}$ & & $\mathbf{X}$ & $\mathbf{x}$ & $\mathbf{x}$ & & $\mathbf{X}$ & $\mathbf{X}$ & $\mathbf{X}$ & $\mathbf{X}$ & \\
\hline Before $\neq$ After & $\mathbf{x}$ & $\mathbf{x}$ & $x$ & & $x$ & $\mathbf{x}$ & $\mathbf{x}$ & $x$ & & & $x$ & $x$ & $x$ & $x$ & \\
\hline During $\neq$ After & $\mathrm{x}$ & & & $\mathrm{x}$ & & $\mathrm{x}$ & & & $\mathrm{x}$ & $\mathrm{x}$ & $\mathrm{x}$ & & & & $\mathrm{x}$ \\
\hline
\end{tabular}

The power draw to the primary crushers for the two lines was not significantly different before, during, or after this test, even though their performance did change during the test; apparently both crushers reacted similarly (less grinding energy required) even though their feedstock was different. Overall, the results to date for test \#2 are less clear-cut than for test \#1. More advanced analysis techniques planned for the next quarter may shed some light on this.

\section{Orebody Models}

The assay, grindability, and liberation data from the exploration cores at Minntac Mine have been composited into ore blocks that correspond to the average size of the working benches. These composited values were plotted in histograms and cumulative curves to enhance visual evaluation of their distinguishing characteristics (Appendix: Charts). Note that the HIS (high silica) and IBC (interbedded chert) designations together correspond to the Lower Slate layer. These designations reflect qualitative differences in crushing and grinding performance observed by U.S. Steel personnel.

\section{Correlation between Minntac Mine and Hibtac Mine}

The two mines operate in the same geological formations, but over the years they have developed different approaches to characterizing the layers. This is due partly to the fact that Minntac mines the Lower Slate as well as the Lower Chert, floating off excess silica after concentration by magnetic separation, while Hibtac works entirely within the Lower Chert, relying entirely on the results of magnetic separation. 


\section{Future Work}

\section{Data Mining}

Previously collected data at both Hibtac and Minntac Mines will continue to be explored and analyzed, supplemented by discussions with mine and laboratory personnel. This includes data collected during operation of blasthole drills at both mines.

Hibtac Mine has collected a significant amount of information regarding the distribution of particle sizes in their autogenous (AG) mill feed, since particle size is an important control on AG mill performance. Their liberation index data will be studied, as Minntac's A-factor has been. Hibtac personnel have identified a number of issues to study that they do not have time to pursue. These will be explored in more detail by the project team.

\section{Orebody Models}

The Minntac Mine model will continue to be refined and compared to measured data. A model of the Hibtac Mine will be started sometime during the next two quarters.

\section{Ore Segregation Tests}

More sophisticated statistical analysis is planned for the data produced during both ore segregation tests at Minntac Mine. The Minntac grindability and liberation curve-fit constants $m, b, Y_{0}, C$, and $k$ will be evaluated for their predictive capability for mill performance, by comparing these constants across formation layers, boreholes, and oxidized regions. They also will be compared to drill monitoring data, where available.

Once the muck imaging system comes online at Hibtac Mine, another ore segregation test based on powder factor will be conducted. 


\section{Appendix: Data Summary from Minntac Mine Ore Segregation Test \#2}

\begin{tabular}{|c|c|c|c|c|c|c|c|c|c|c|c|c|c|c|}
\hline & \multicolumn{4}{|c|}{ Secondary Crusher Power } & \multicolumn{5}{|c|}{ Rod Mill \#2 Feed (R2S) } & \multicolumn{5}{|c|}{ Rod Mill \#3 Feed (R3S) } \\
\hline & $1 \& 2$ & $1 \& 2$ & $3 \& 4$ & $3 \& 4$ & ICP & $\mathrm{ICP}$ & ICP & ICP & ICP & ICP & ICP & $\mathrm{ICP}$ & ICP & ICP \\
\hline AVERAGES & crush - idle & $W+E$ & crush - idle & $W+E$ & $\mathrm{Al}$ & $\mathrm{Ca}$ & $\mathrm{Mg}$ & $\mathrm{Mn}$ & $\mathrm{SiO}_{2}$ & $\mathrm{Al}$ & $\mathrm{Ca}$ & $\mathrm{Mg}$ & $\mathrm{Mn}$ & $\mathrm{SiO}_{2}$ \\
\hline Before Test & 335 & 300 & 334 & 289 & 0.0483 & 0.298 & 0.227 & 0.0867 & 4.99 & 0.0517 & 0.273 & 0.230 & 0.0800 & 5.12 \\
\hline During Test & 306 & 261 & 310 & 271 & 0.0425 & 0.244 & 0.171 & 0.1300 & 4.12 & 0.0763 & 0.223 & 0.266 & 0.0950 & 6.18 \\
\hline After Test & 333 & 284 & 339 & 279 & 0.0567 & 0.218 & 0.198 & 0.0950 & 4.71 & 0.0550 & 0.213 & 0.187 & 0.0900 & 4.58 \\
\hline \multicolumn{15}{|l|}{ STD DEVIATIONS } \\
\hline \begin{tabular}{|r|} 
Before Test \\
\end{tabular} & 31.7 & 44.7 & 18.1 & 16.7 & 0.00408 & 0.0637 & 0.0163 & 0.0216 & 0.558 & 0.00753 & 0.0615 & 0.0228 & 0.0200 & 0.310 \\
\hline During Test & 24.7 & 21.4 & 63.0 & 28.4 & 0.00463 & 0.1070 & 0.0398 & 0.0200 & 0.324 & 0.00744 & 0.0537 & 0.0540 & 0.0169 & 0.490 \\
\hline After Test & 15.1 & 28.0 & 31.8 & 32.8 & 0.00516 & 0.0349 & 0.0172 & 0.0207 & 0.175 & 0.00837 & 0.0484 & 0.0339 & 0.0200 & 0.621 \\
\hline \multicolumn{15}{|l|}{$90 \%$ CONFIDENCE LIMITS } \\
\hline Before Test & 13.9 & 19.6 & 7.93 & 7.32 & 0.00336 & 0.0524 & 0.0134 & 0.0178 & 0.459 & 0.00619 & 0.0506 & 0.0188 & 0.0165 & 0.255 \\
\hline During Test & 9.29 & 8.06 & 23.7 & 10.71 & 0.00310 & 0.0717 & 0.0267 & 0.0134 & 0.217 & 0.00498 & 0.0359 & 0.0362 & 0.0113 & 0.328 \\
\hline After Test & 6.00 & 11.12 & 12.6 & 13.07 & 0.00425 & 0.0287 & 0.0142 & 0.0171 & 0.144 & 0.00688 & 0.0398 & 0.0279 & 0.0165 & 0.511 \\
\hline
\end{tabular}

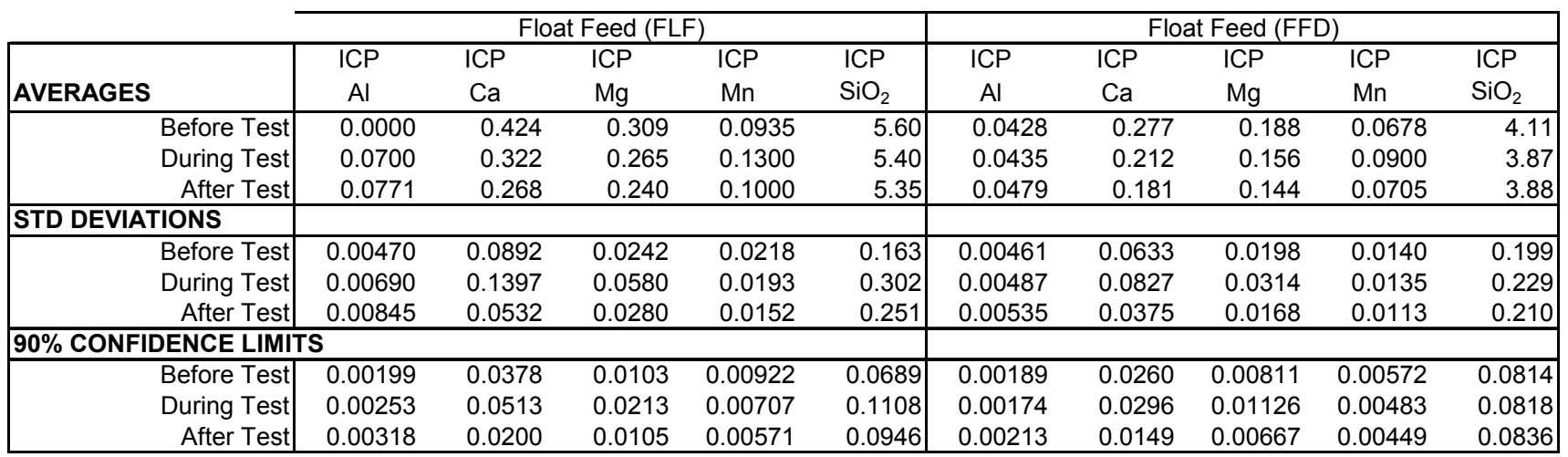

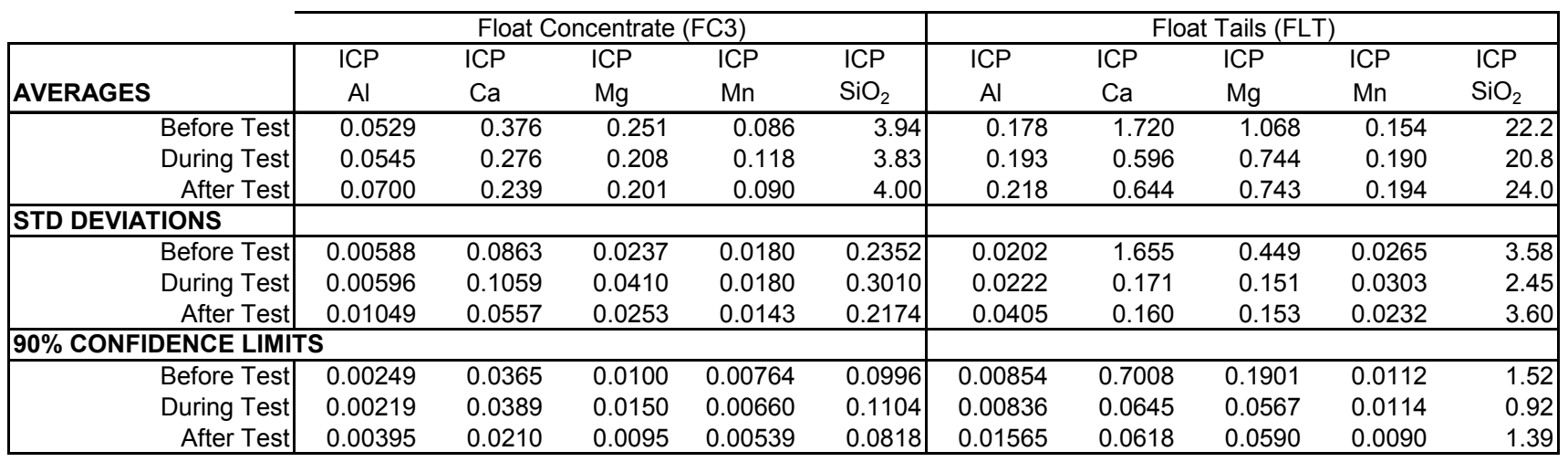


Terms and abbreviations:

RMF rod mill feed

Con concentrate

Crs coarse

Fne fine

Mag Fe magnetic iron

$\mathrm{kwh} / \mathrm{t}$ kilowatt-hours/ton

NOLA nuclear on-line analyzer

FLF \& FFD flotation cell feed

FC3 flotation concentrate (output value)

FLT flotation tails (output waste)
$\mathrm{SiO} 2$ silica

UC Upper Chert formation

HIS high-silica portion of UC

IBC inter-bedded chert portion of UC

L1-2 Lower Slate layers 1 and 2

L3-4 Lower Slate layers 3 and 4

IND TOT indicated total iron

TLS tailings

ICP inductively coupled plasma analysis 


\section{Appendix: Charts from Minntac Mine Ore Segregation Test \#2}

\section{Crusher Performance During Minntac Mine Segregation Test \#1}

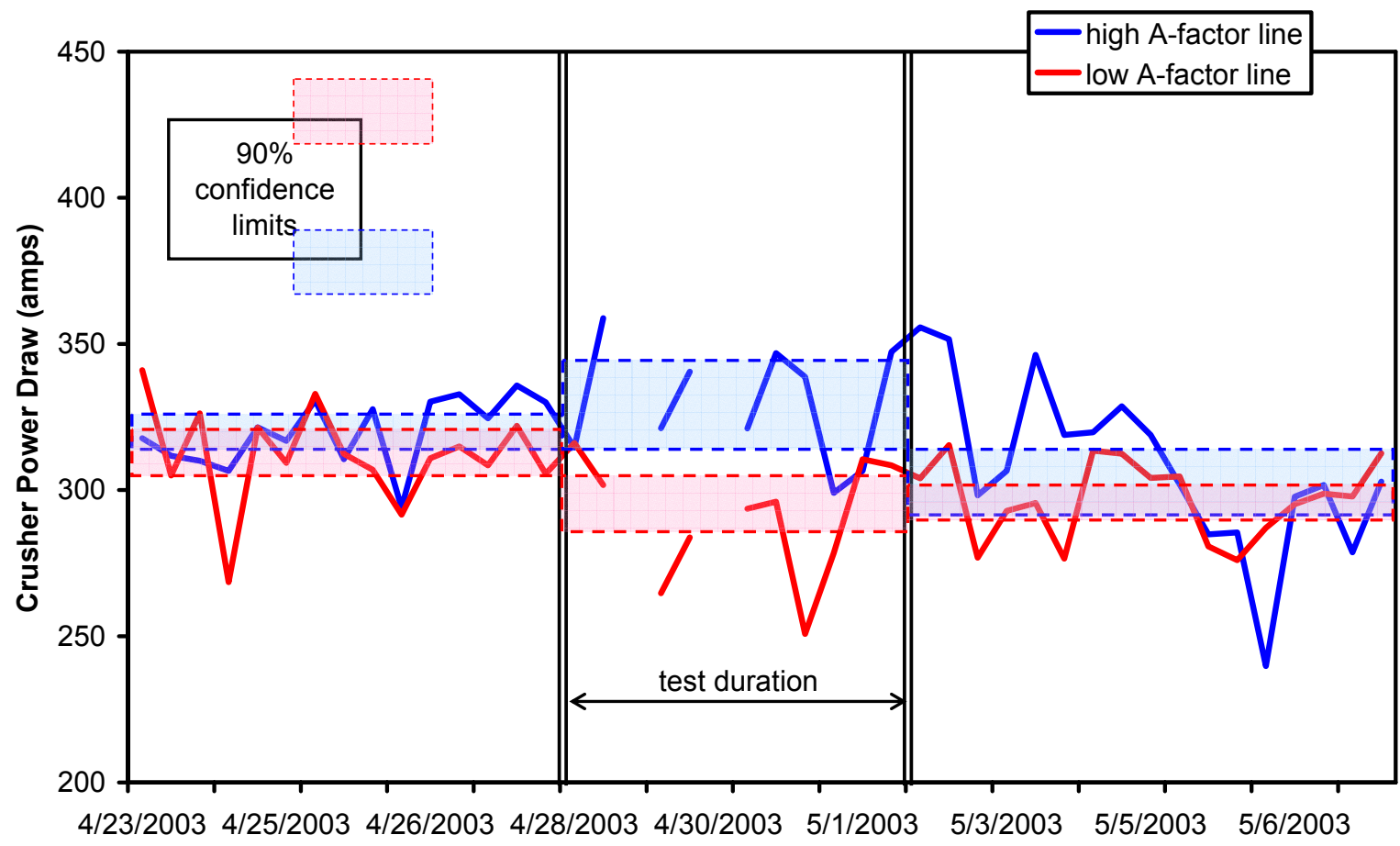

Crusher Performance During Minntac Mine Segregation Test \#2

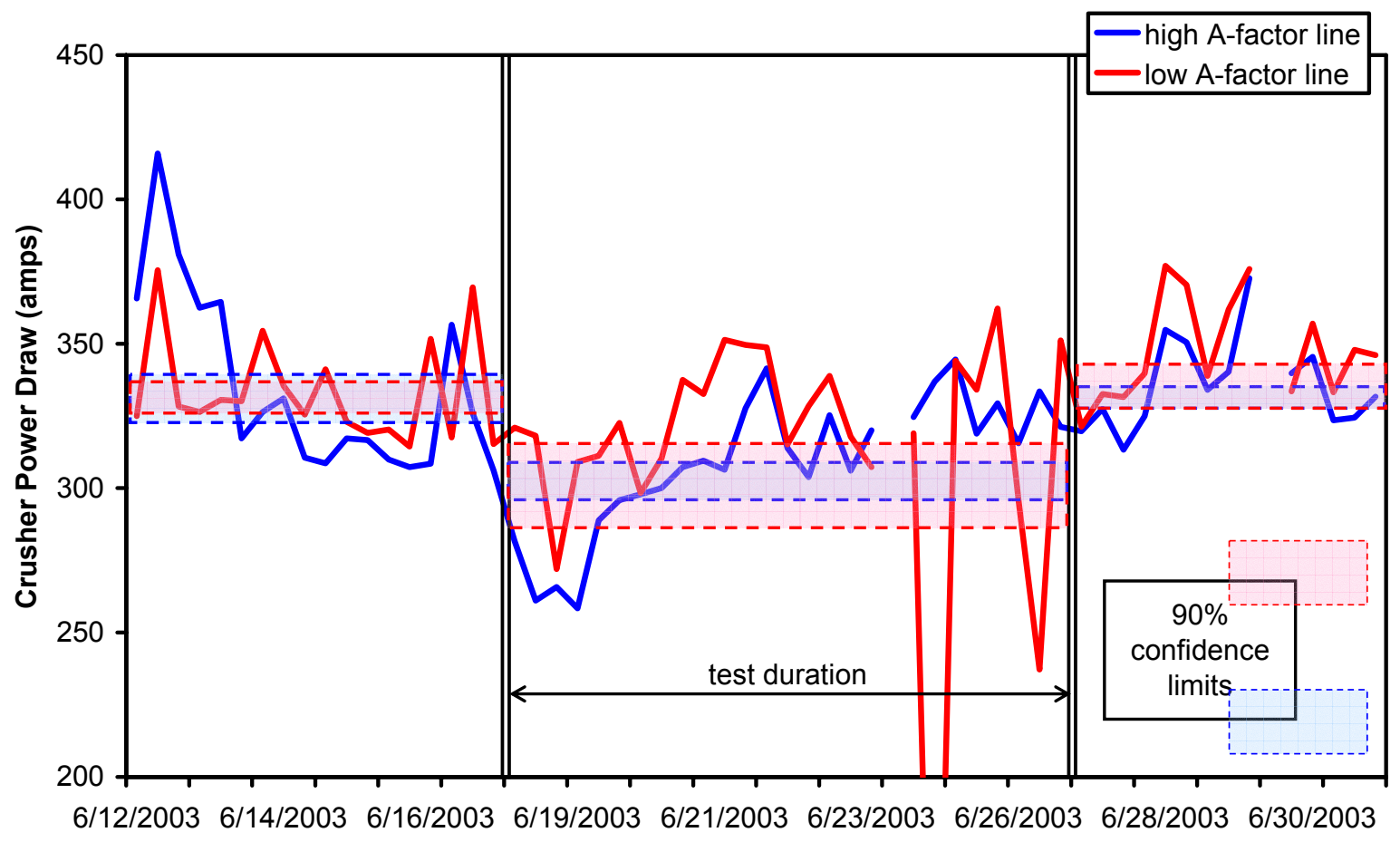


Silica Comparison in Crusher Feed, Minntac Mine Seg Test \#2

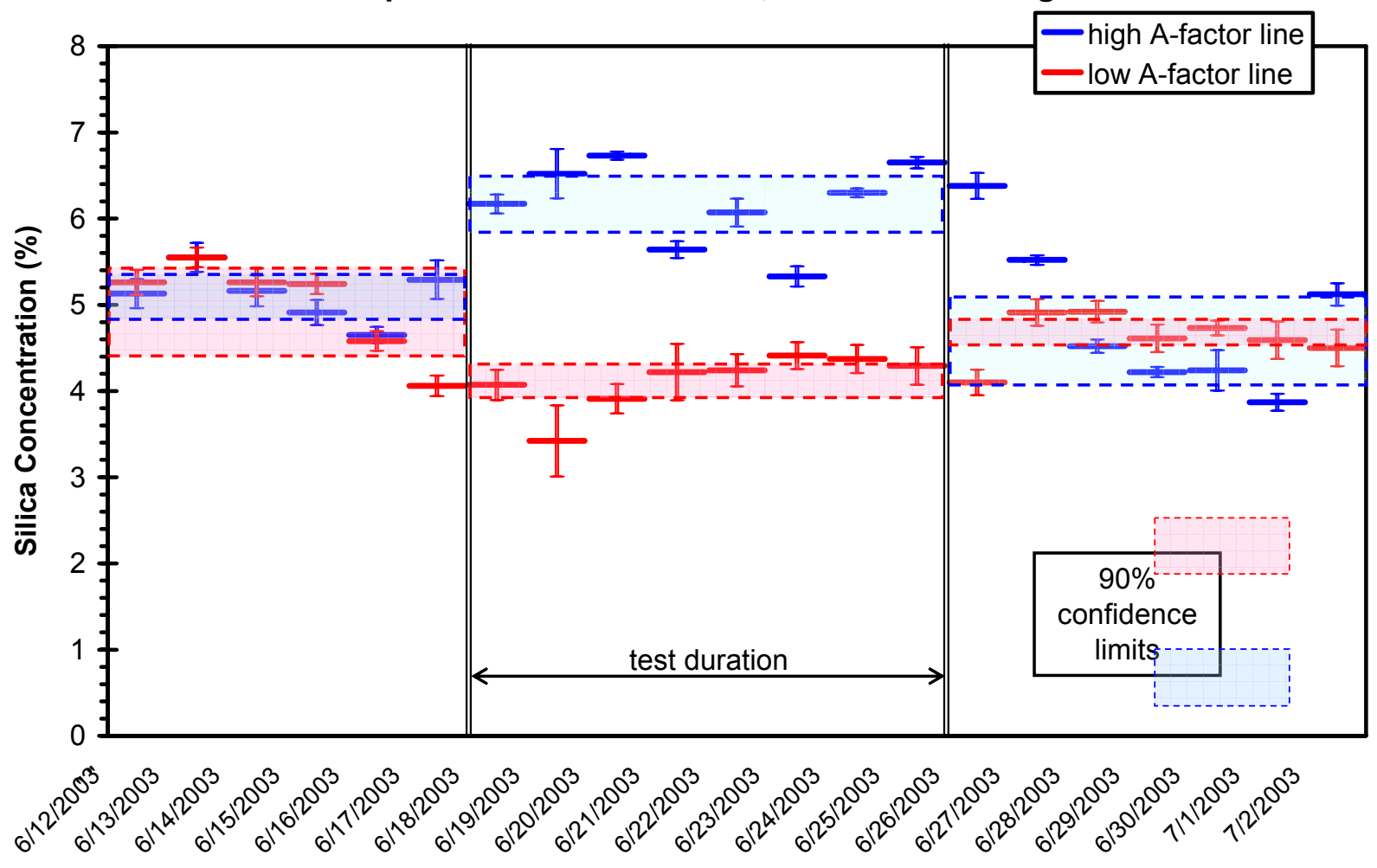

Manganese Comparison in Crusher Feed, Minntac Mine Seg Test \#2

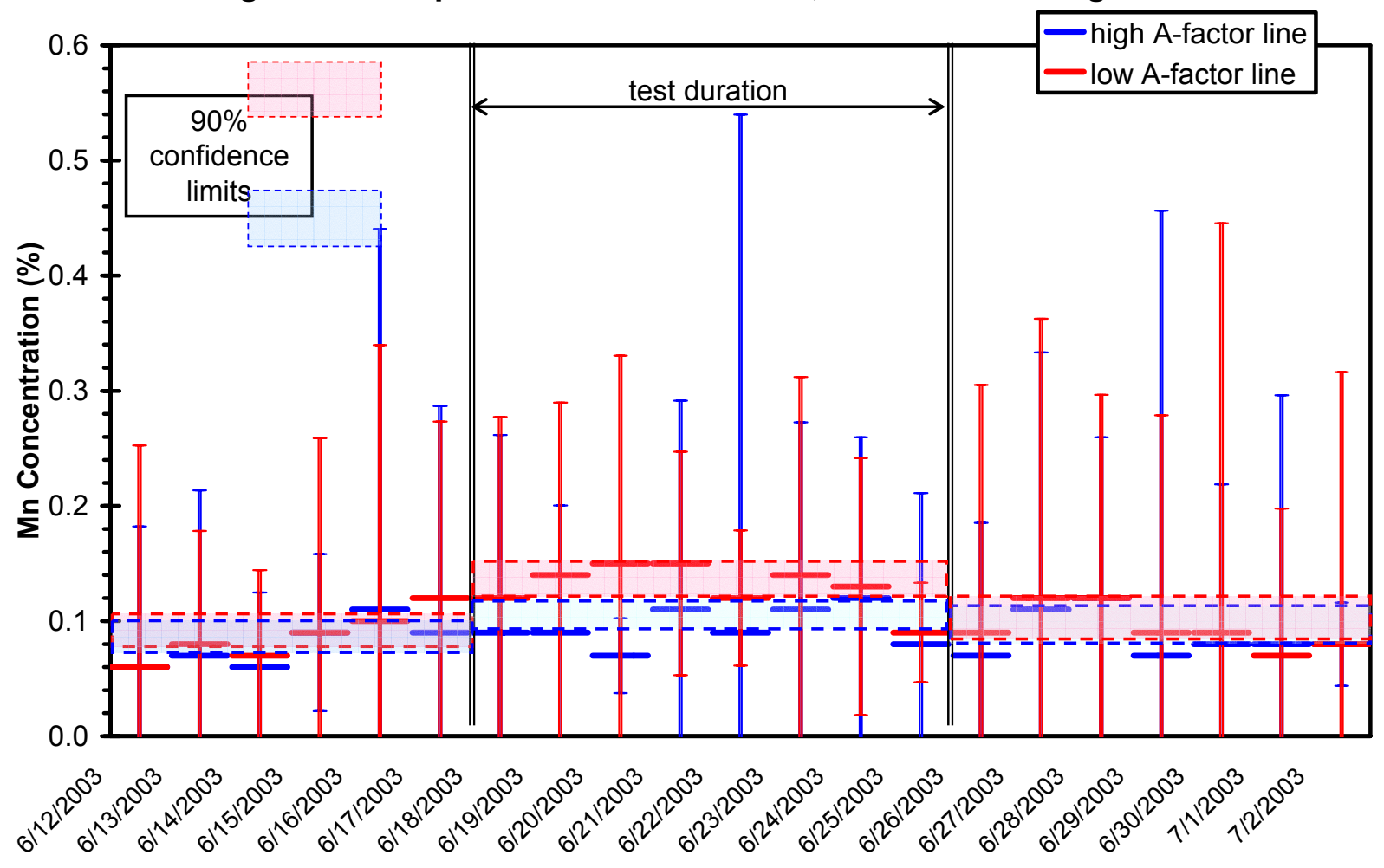


Magnesium Comparison in Crusher Feed, Minntac Mine Seg Test \#2

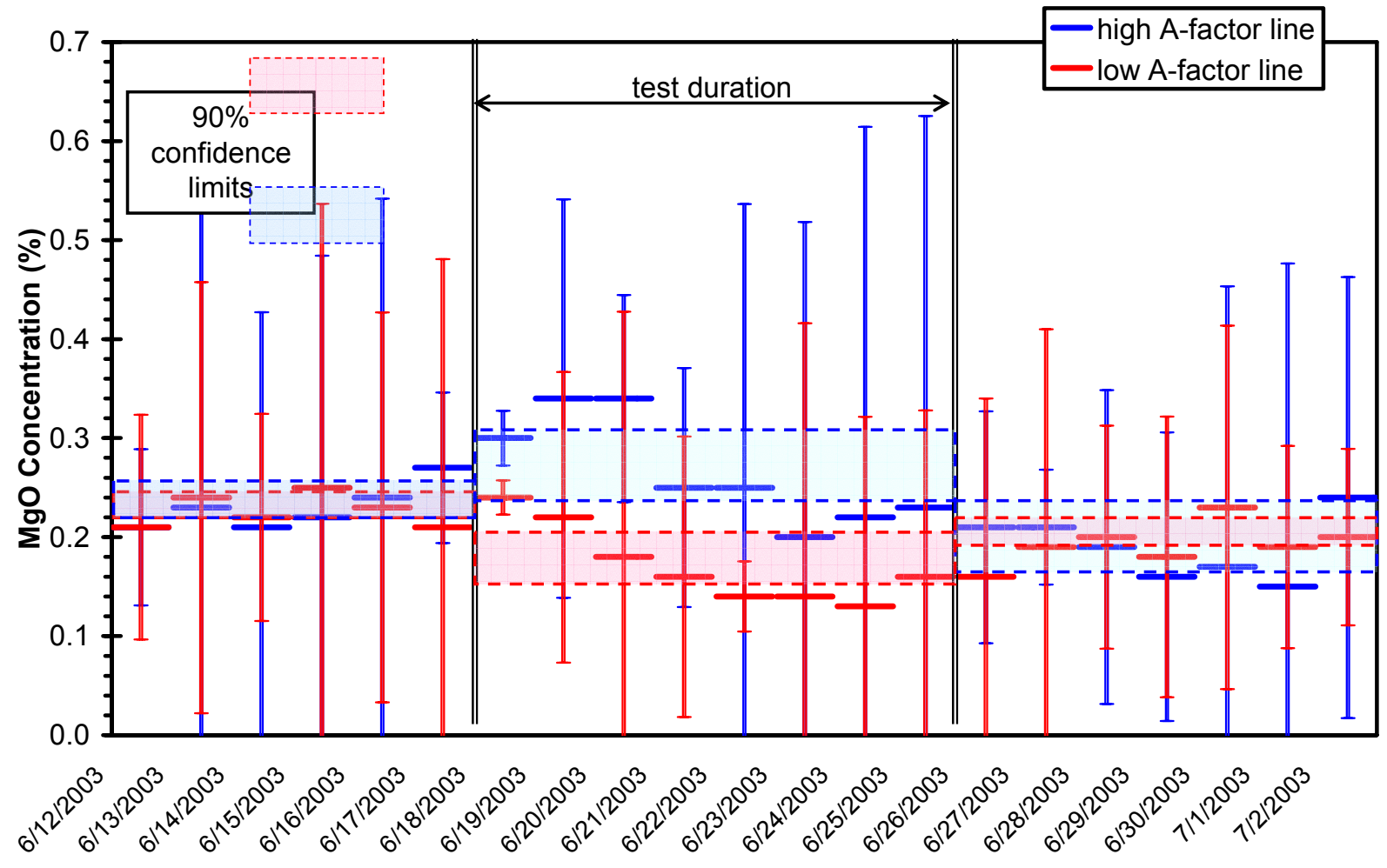

Calcium Comparison in Crusher Feed, Minntac Mine Seg Test \#2

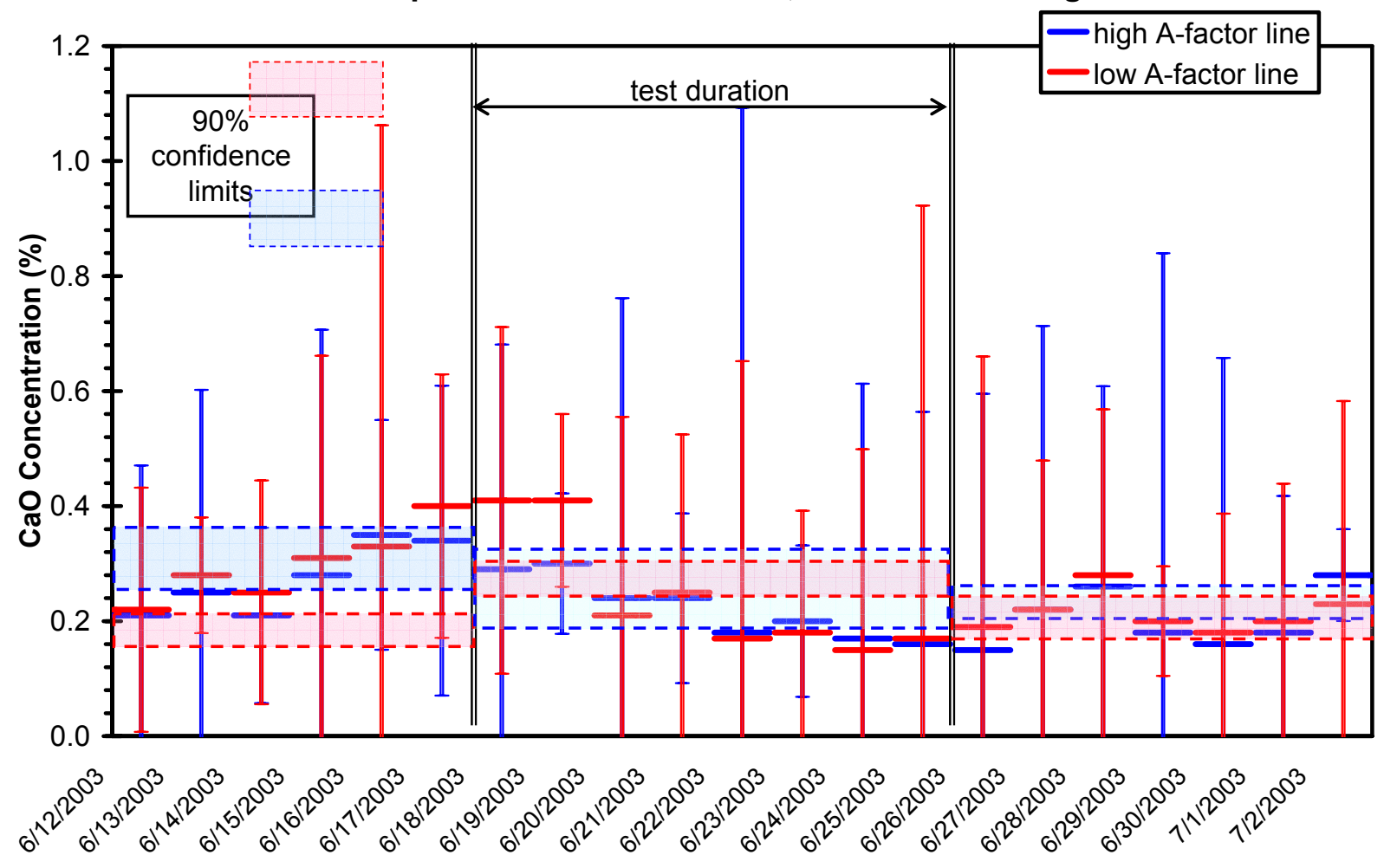




\section{Alumina Comparison in Crusher Feed, Minntac Mine Seg Test \#2}

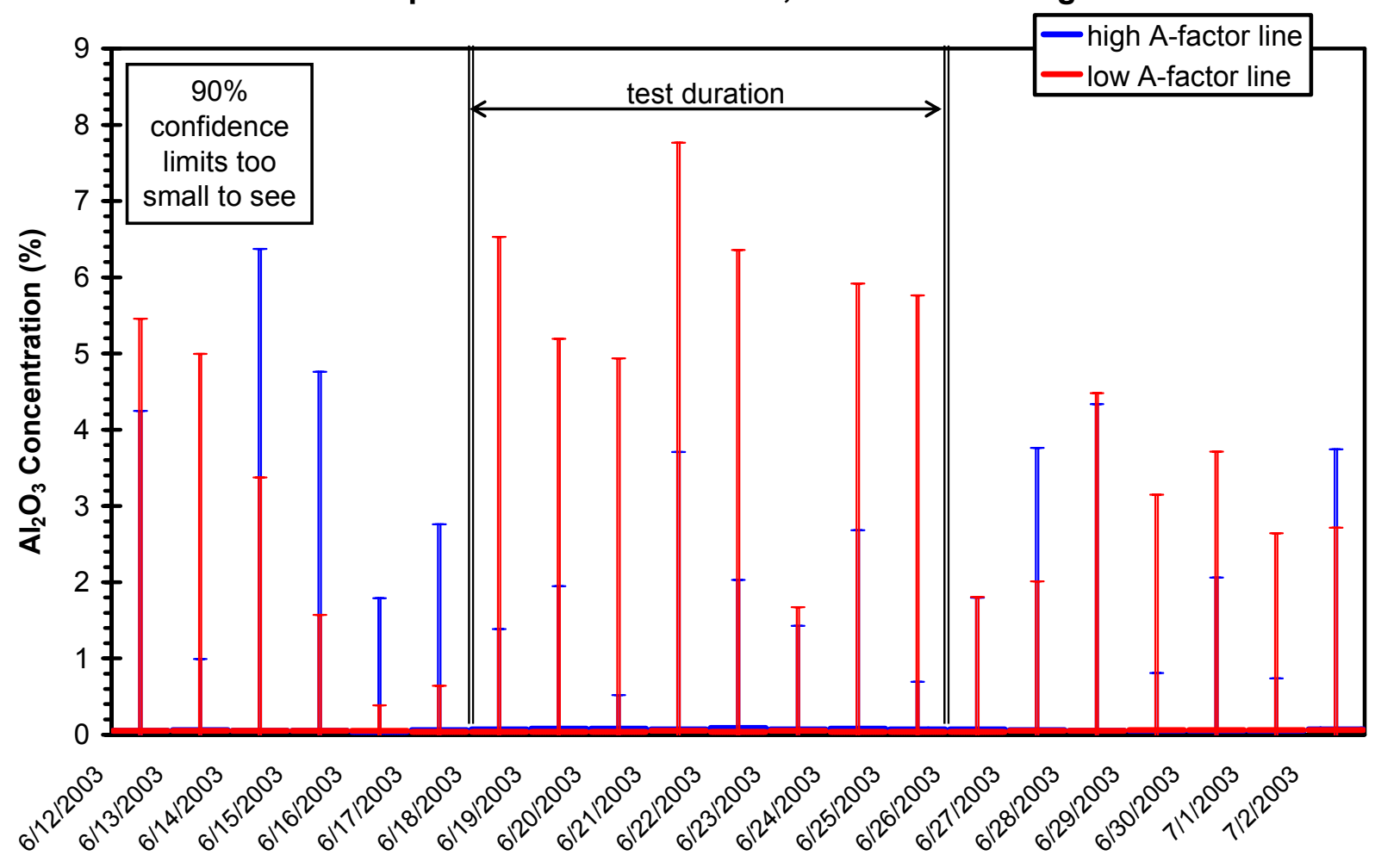


Charts of Ore Grindability, by Layer, from Orebody Model for Minntac Mine
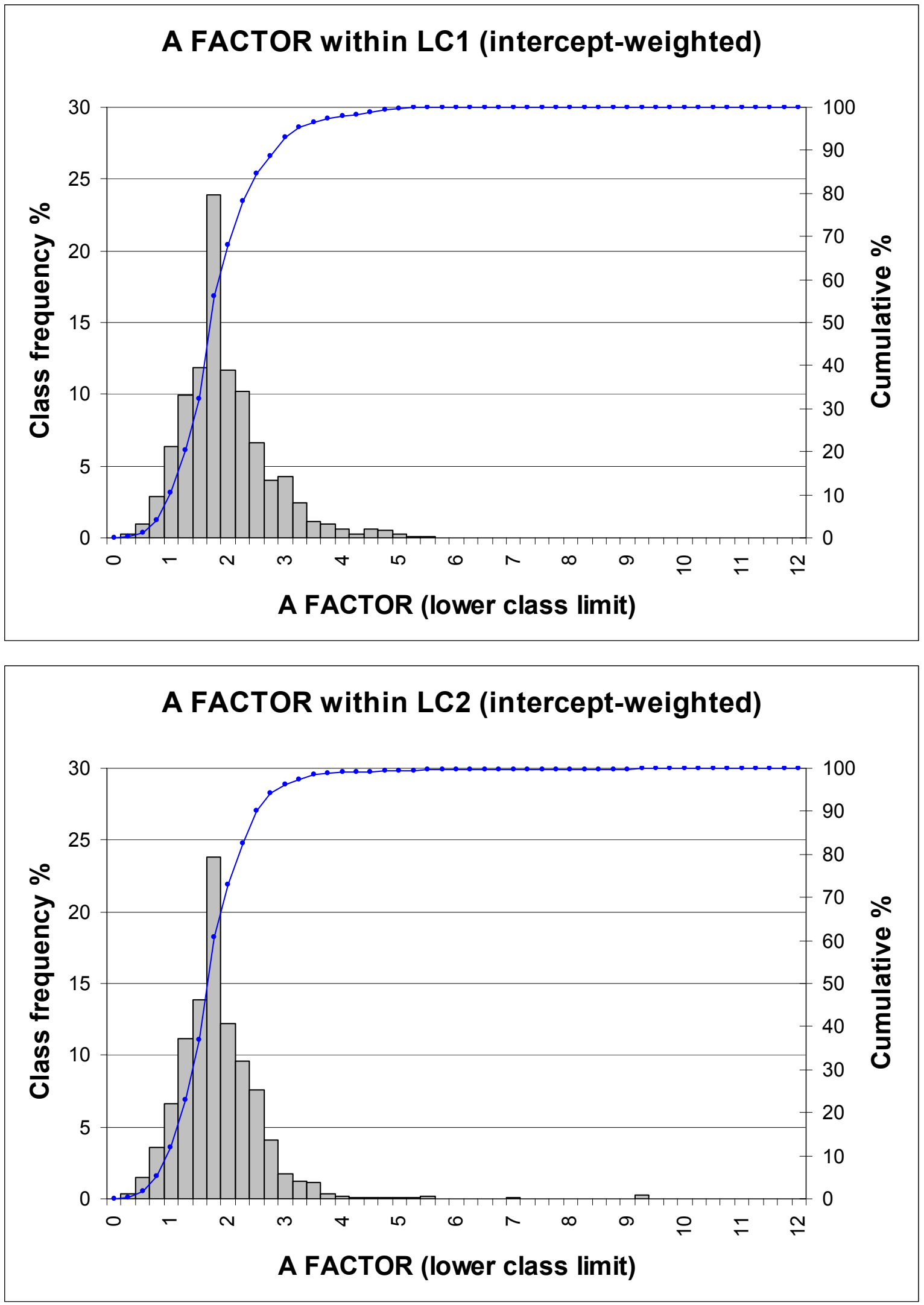

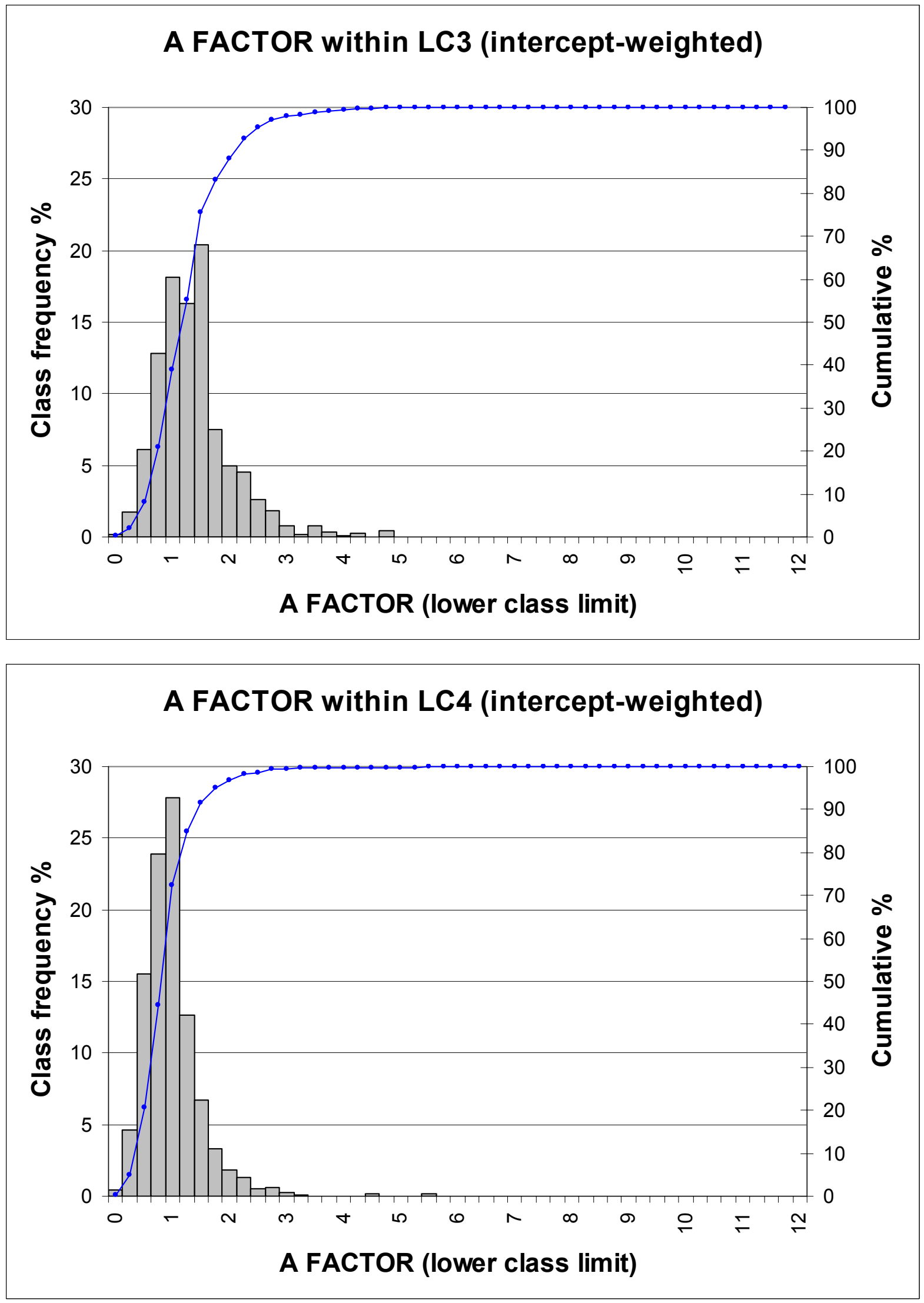

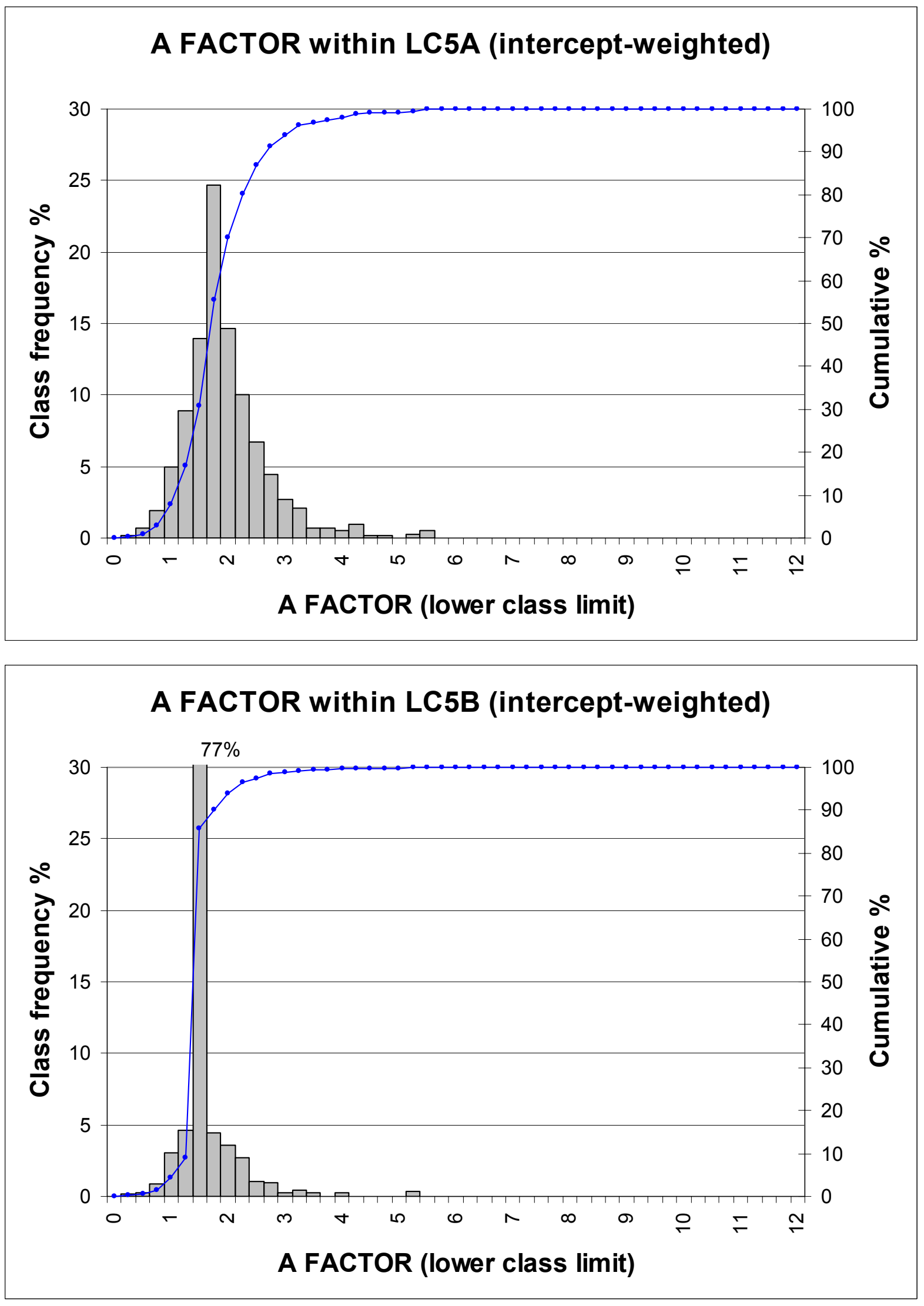

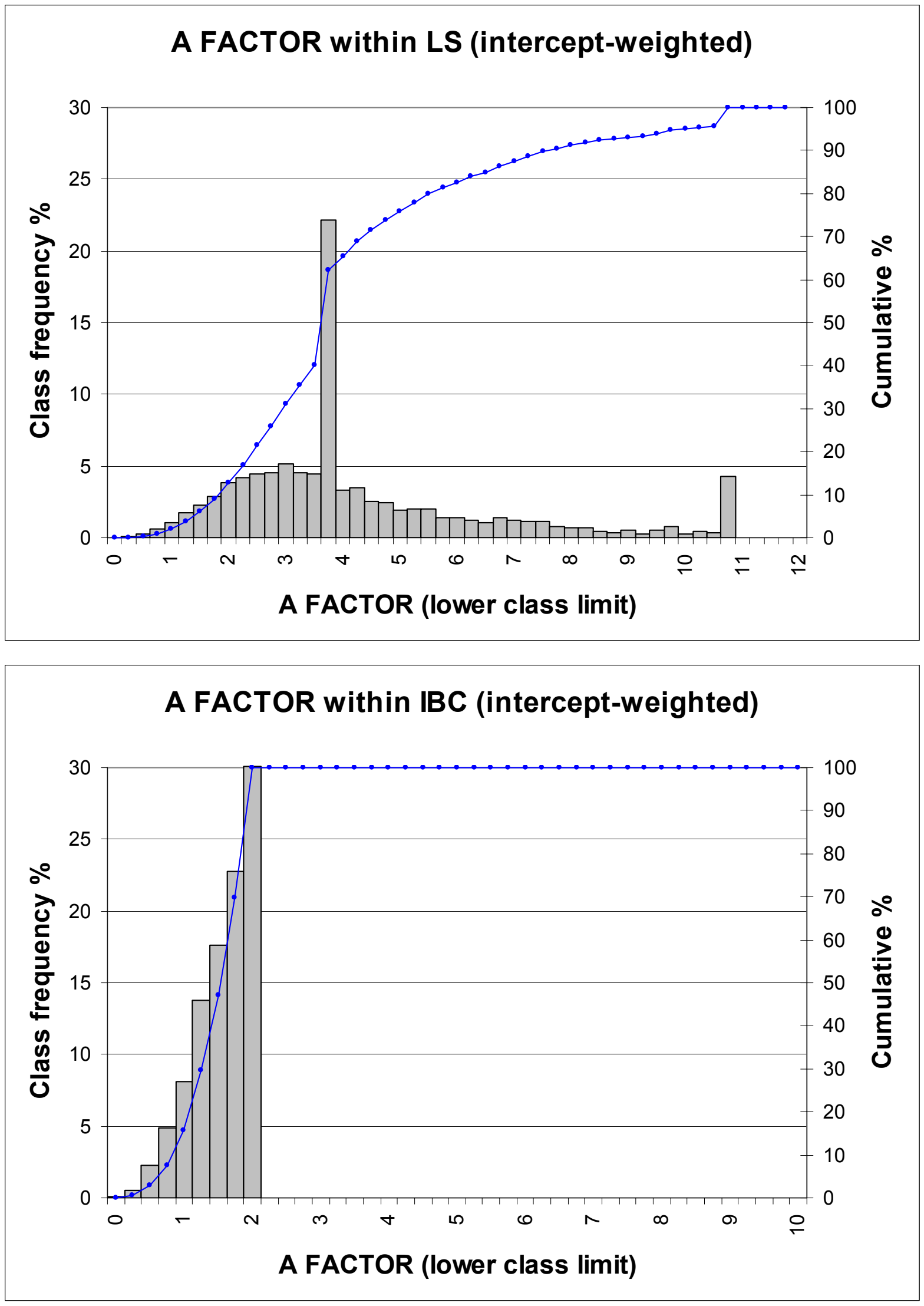

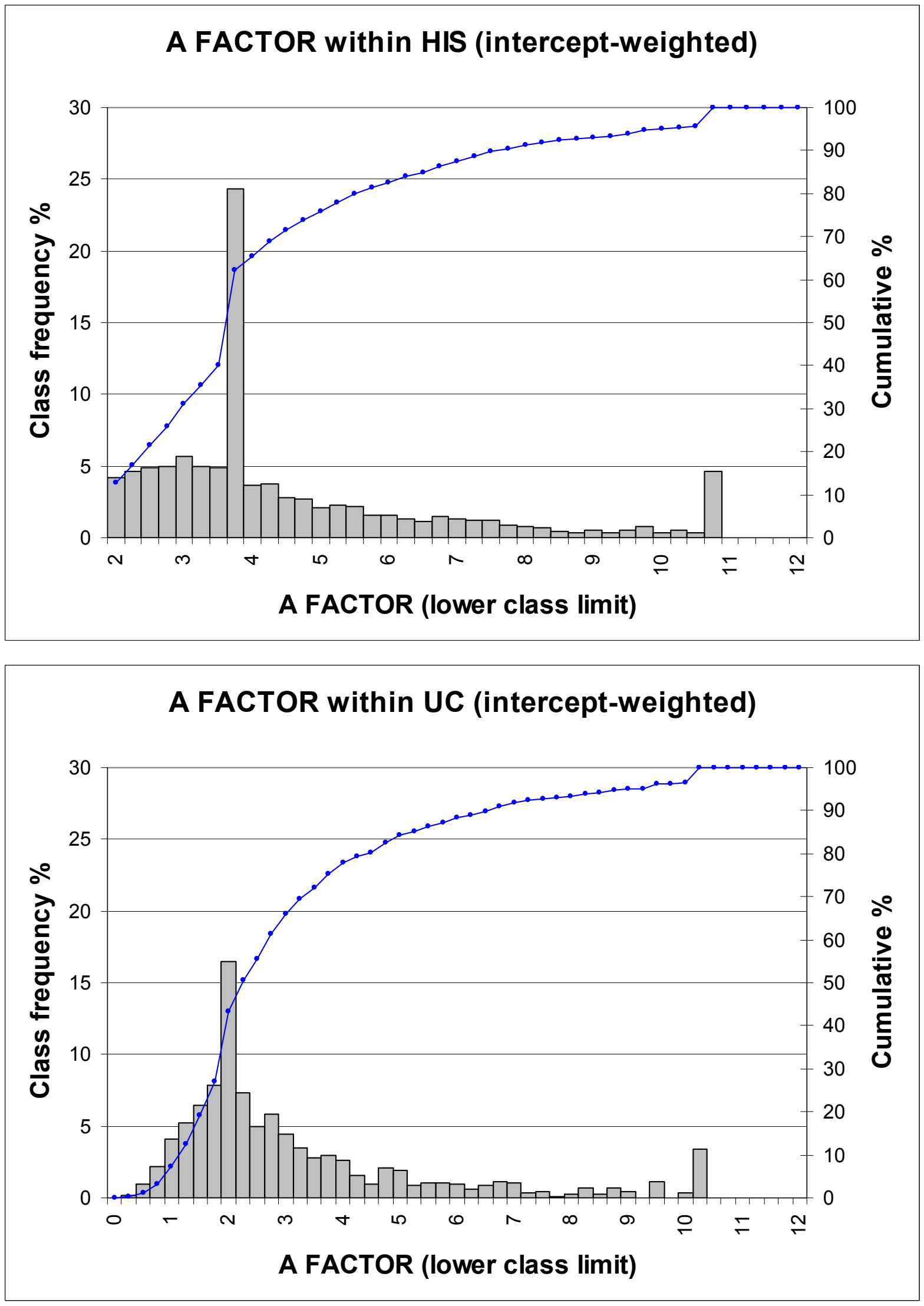
Charts of Iron Content, by Layer, from Orebody Model for Minntac Mine
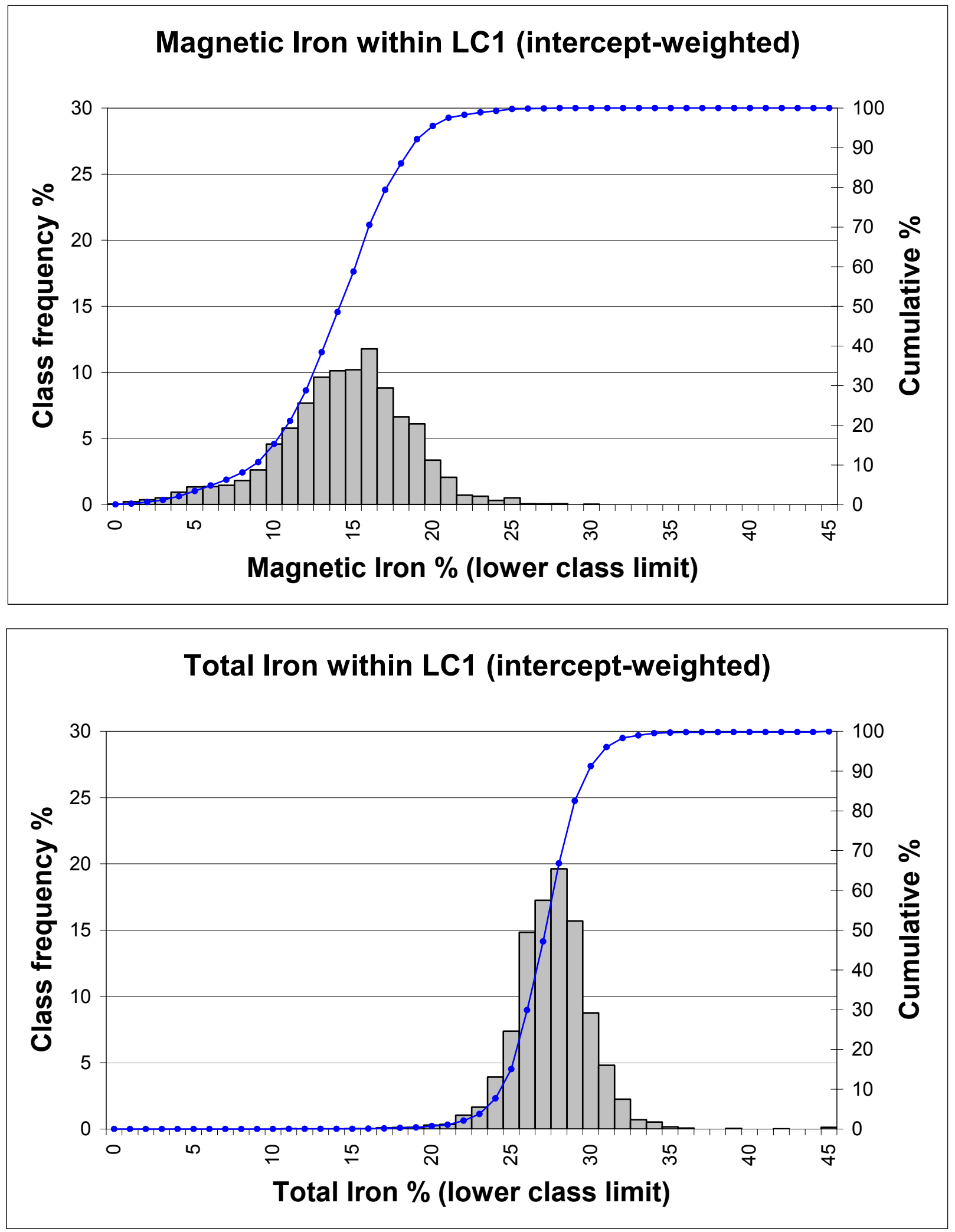

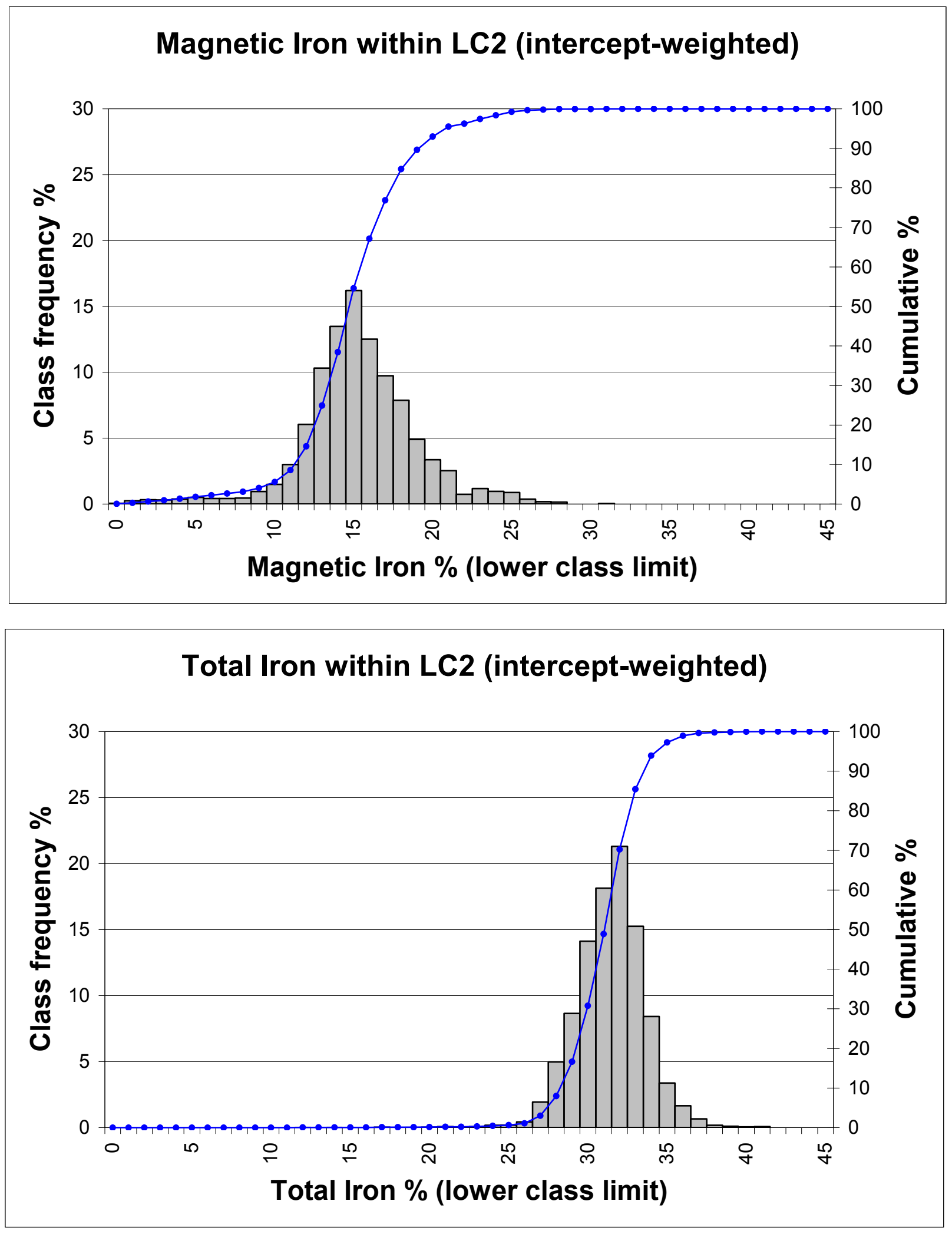

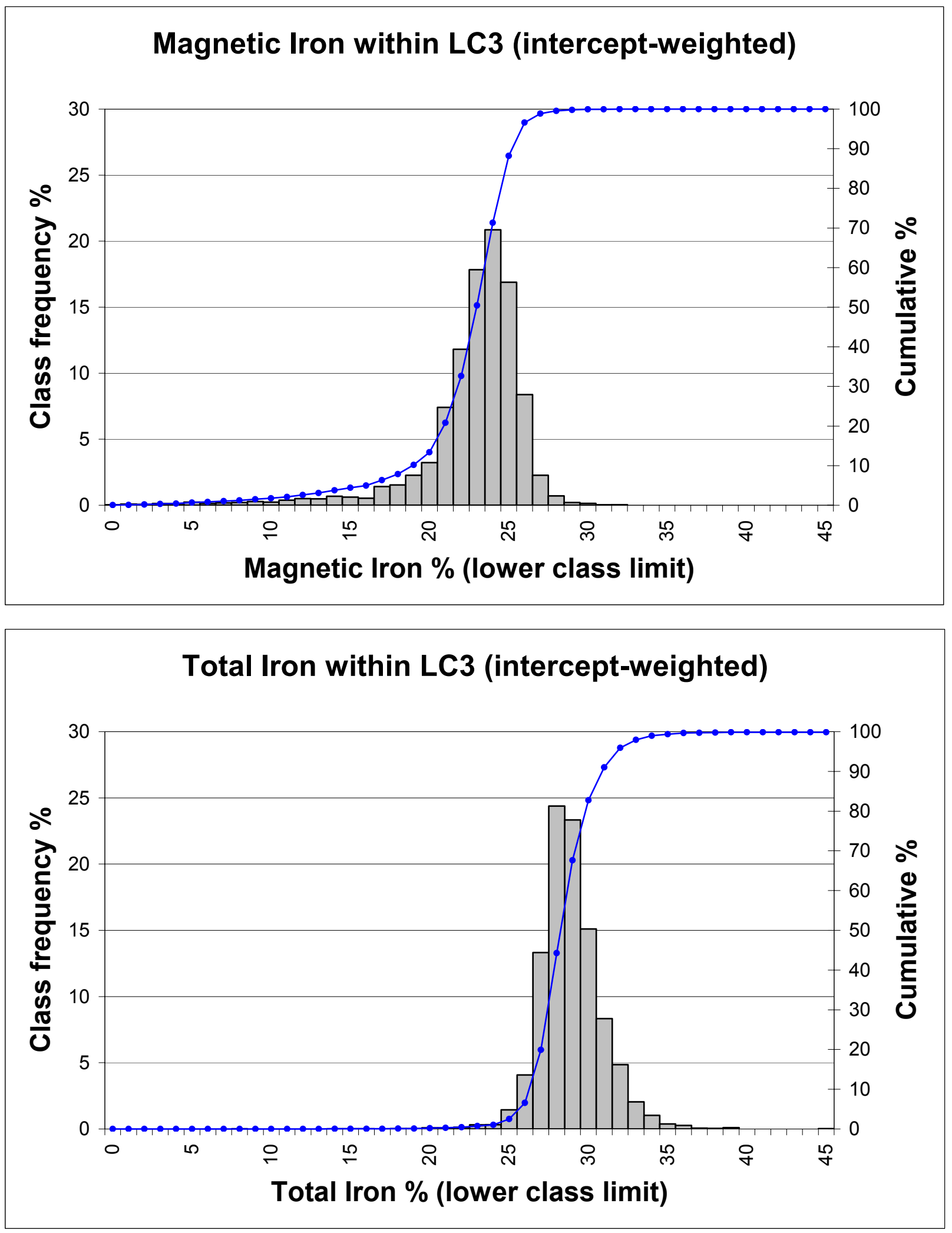

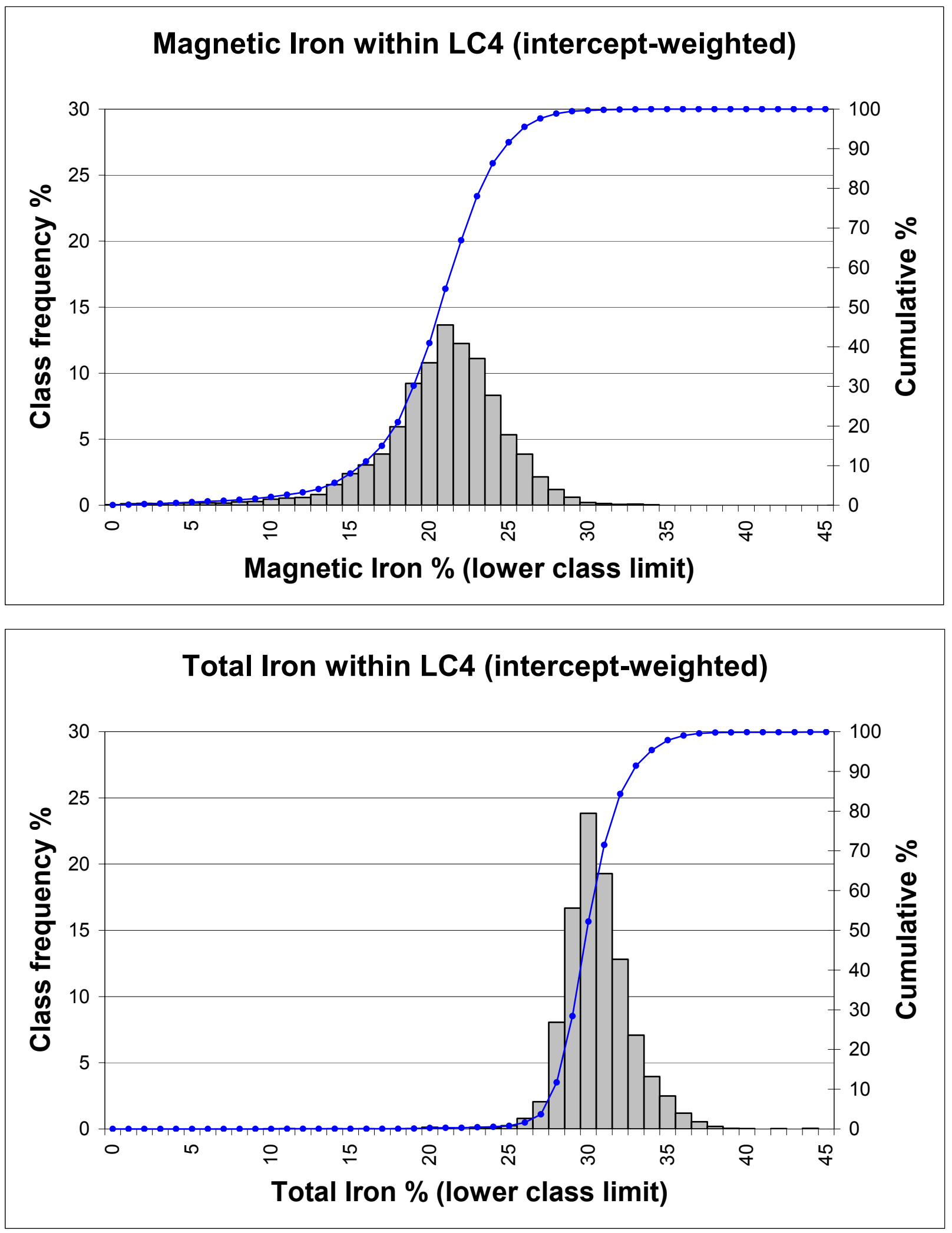

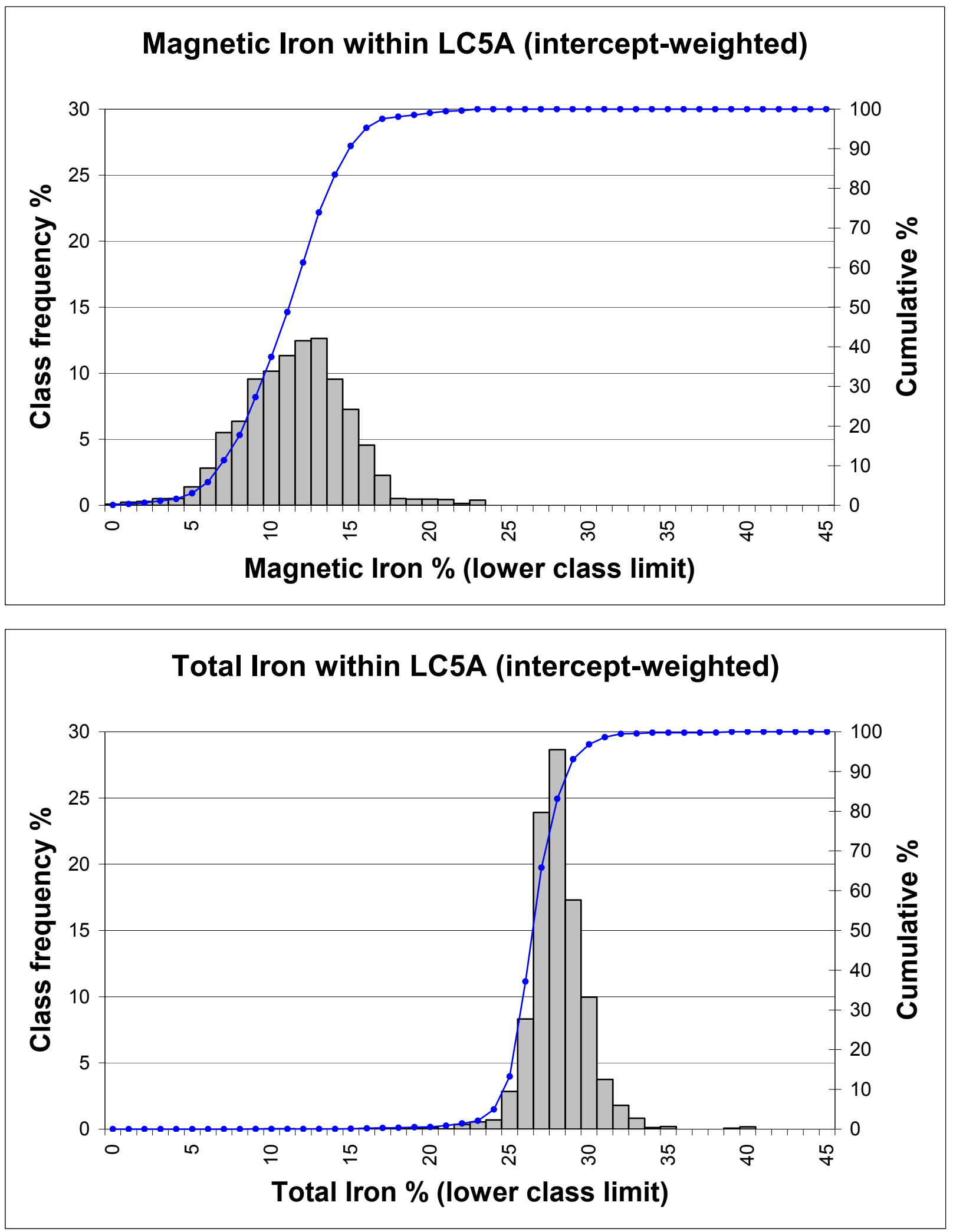

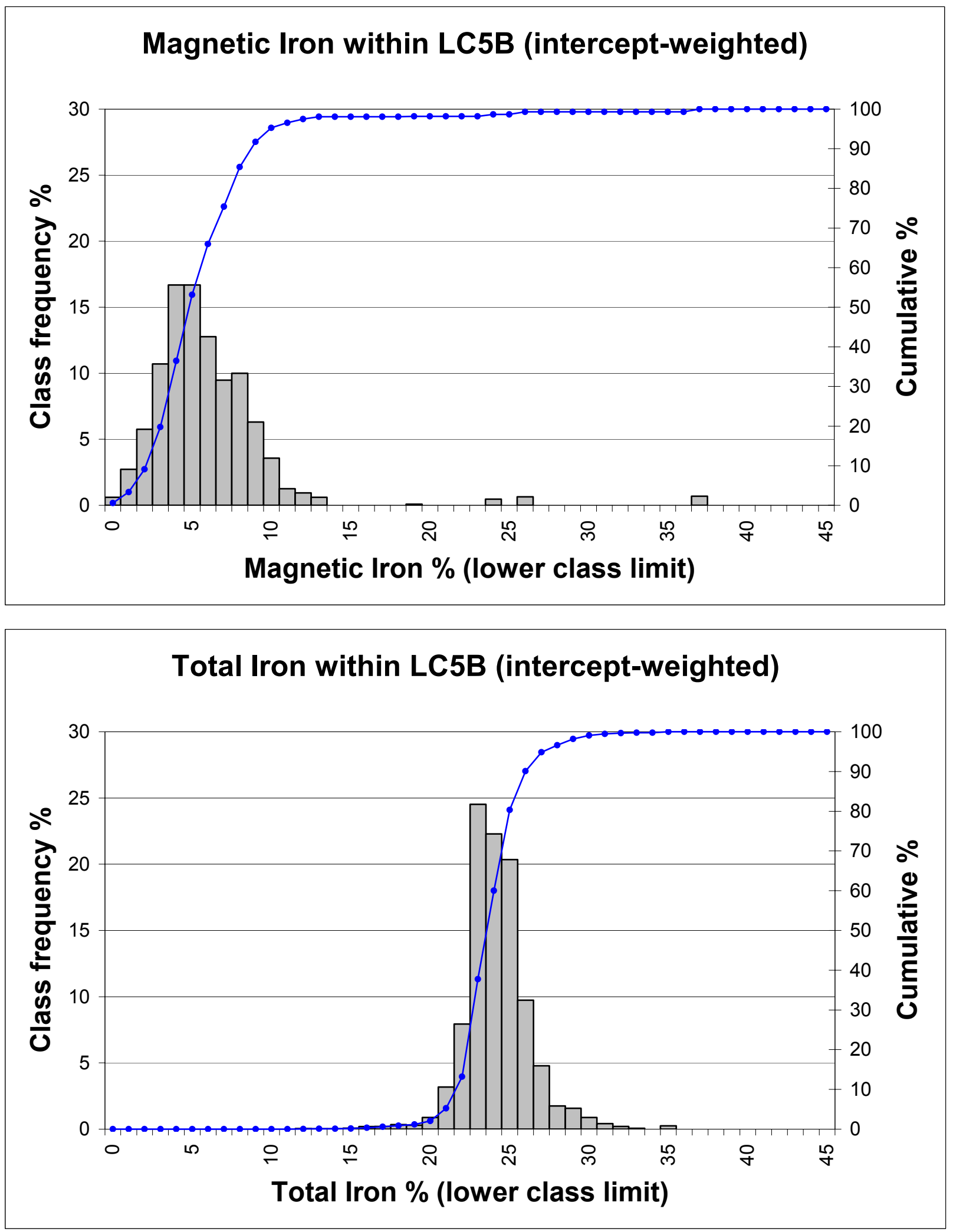

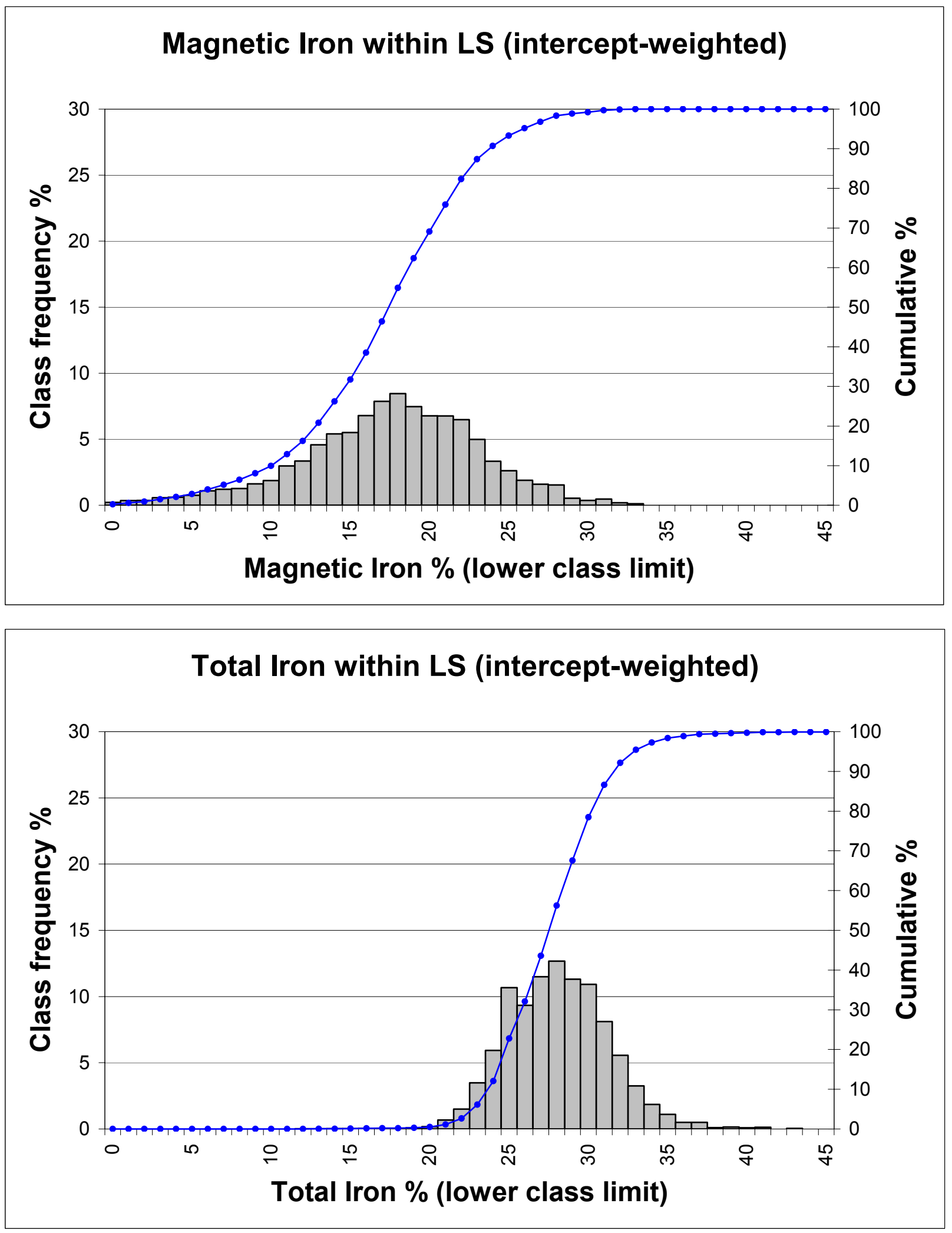

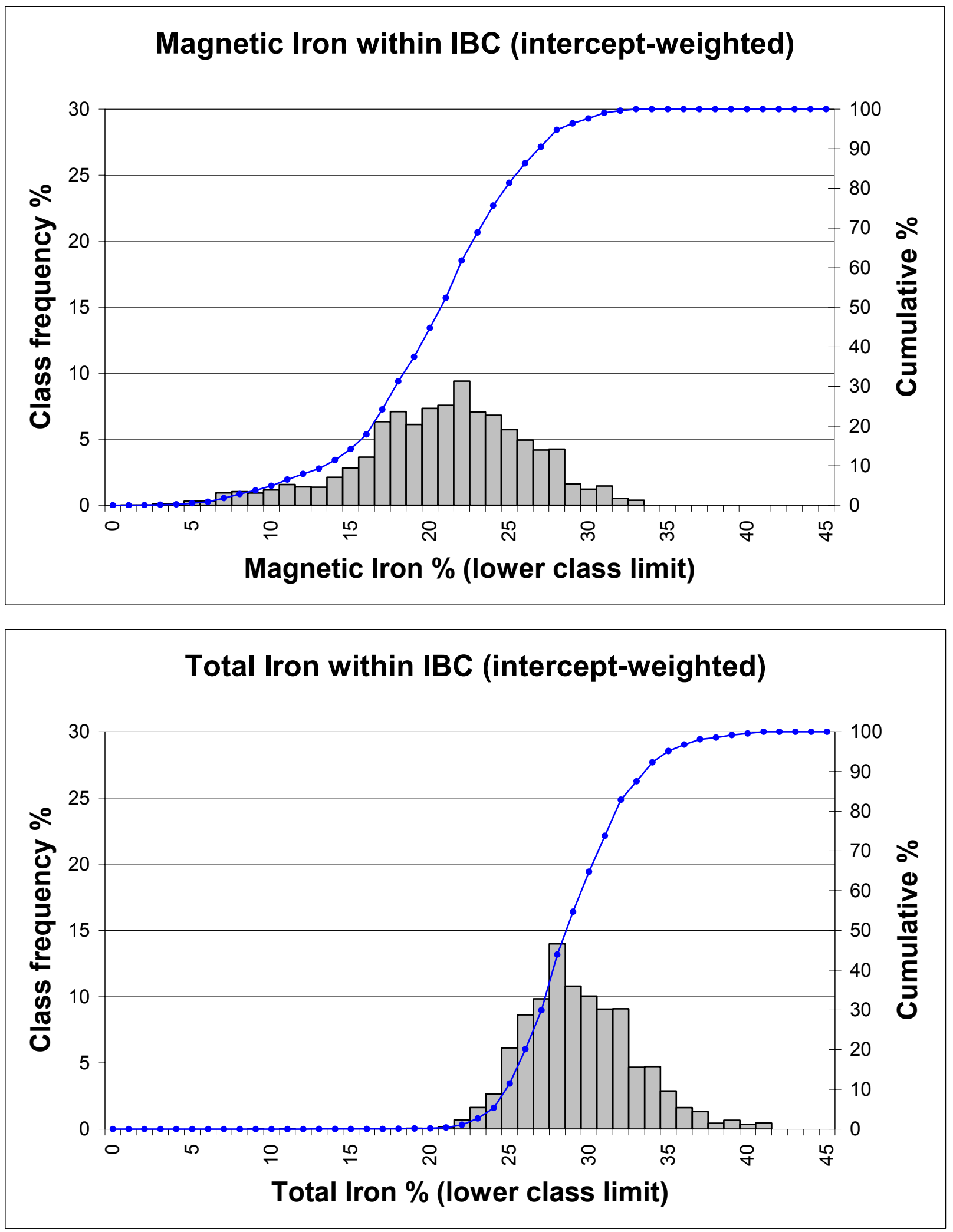

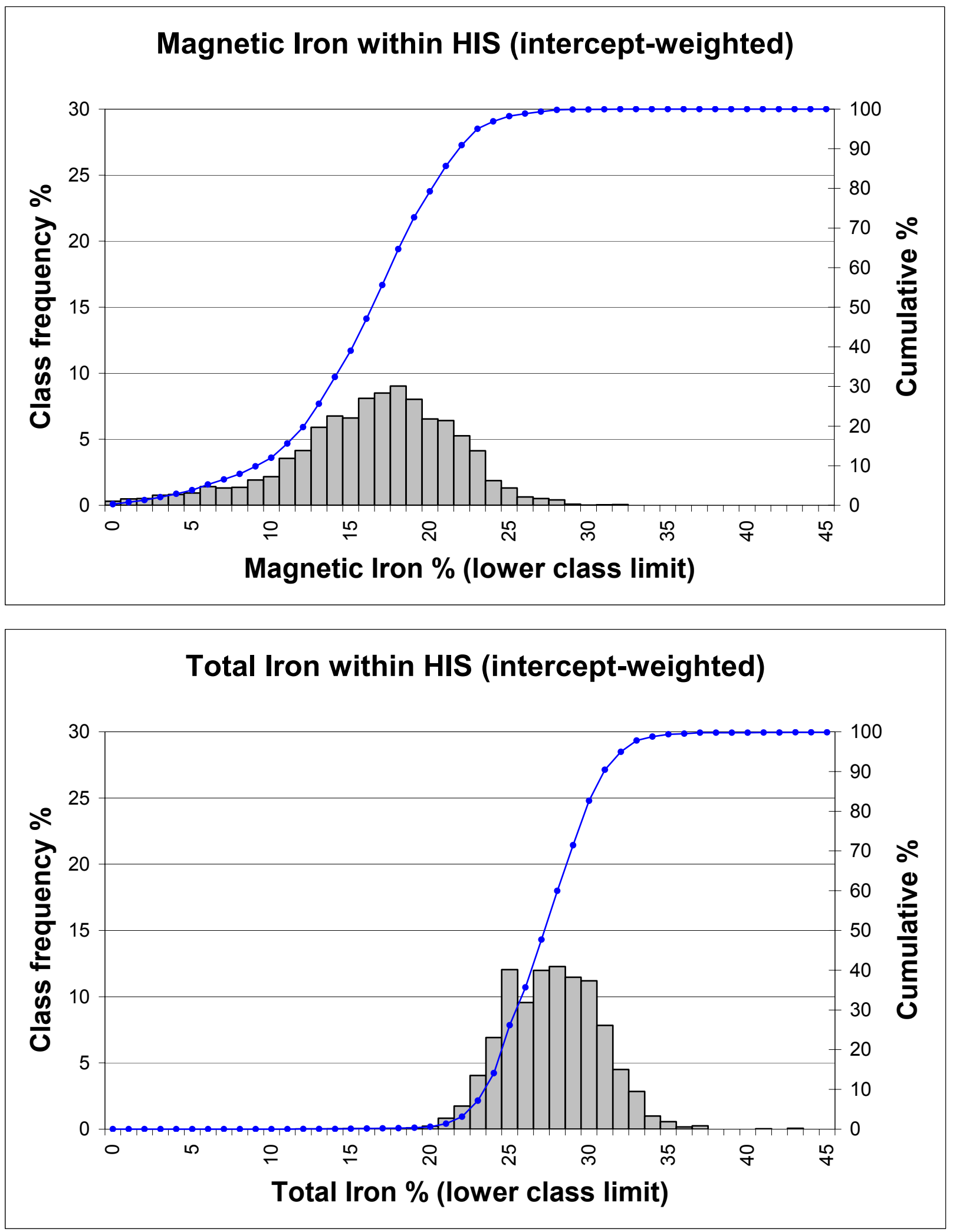

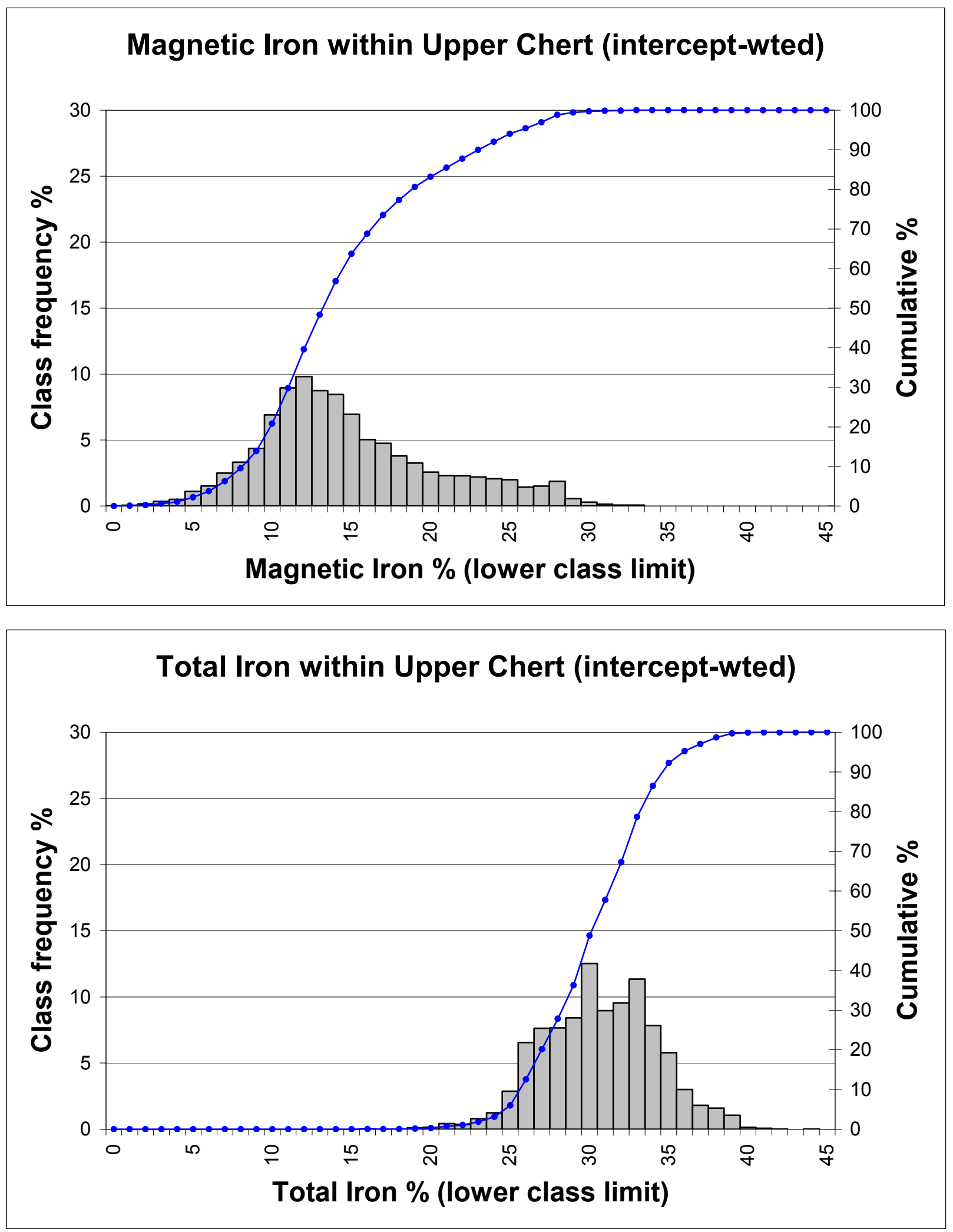
Charts of Concentrate Silica, by Layer, from Orebody Model for Minntac Mine
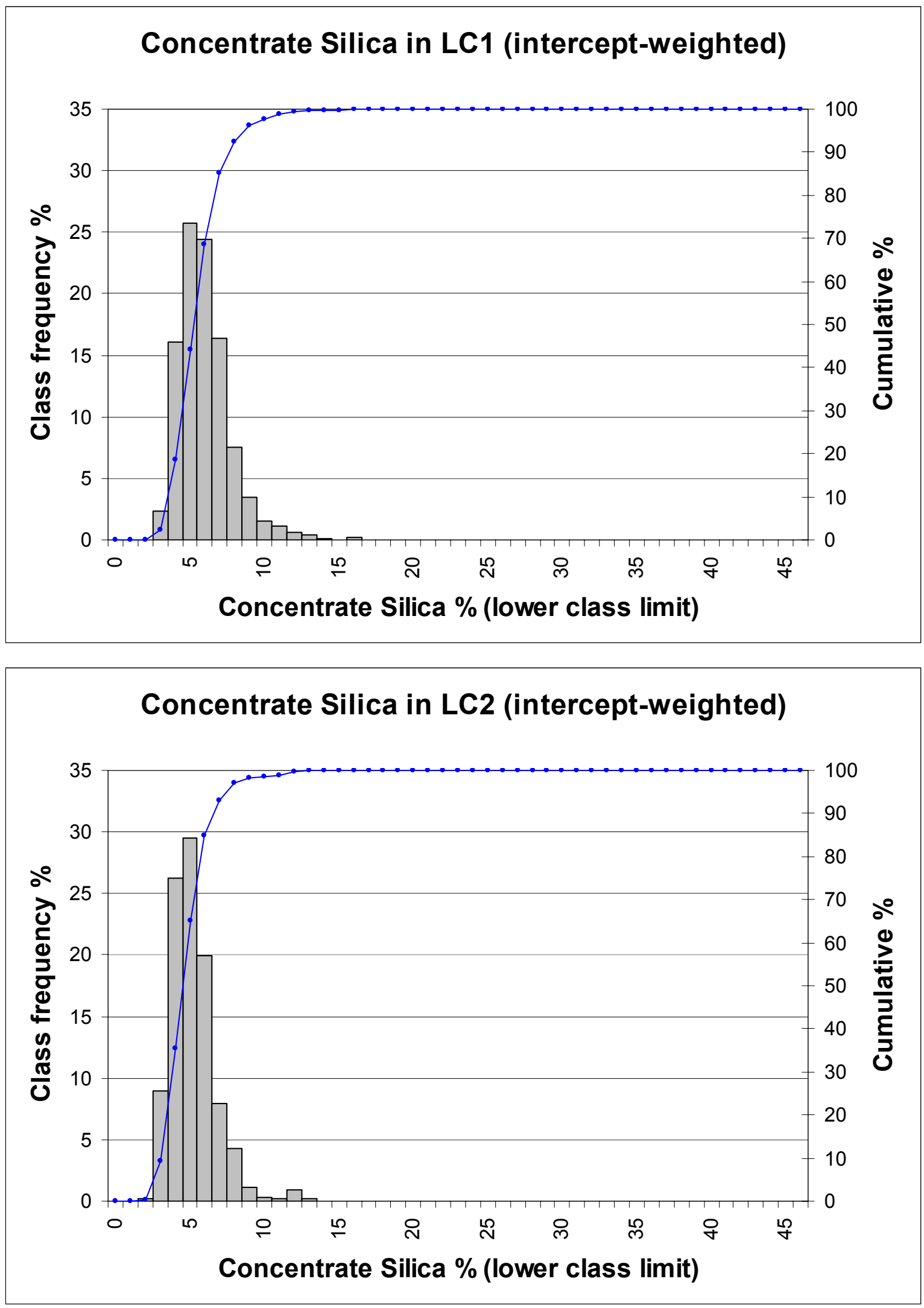

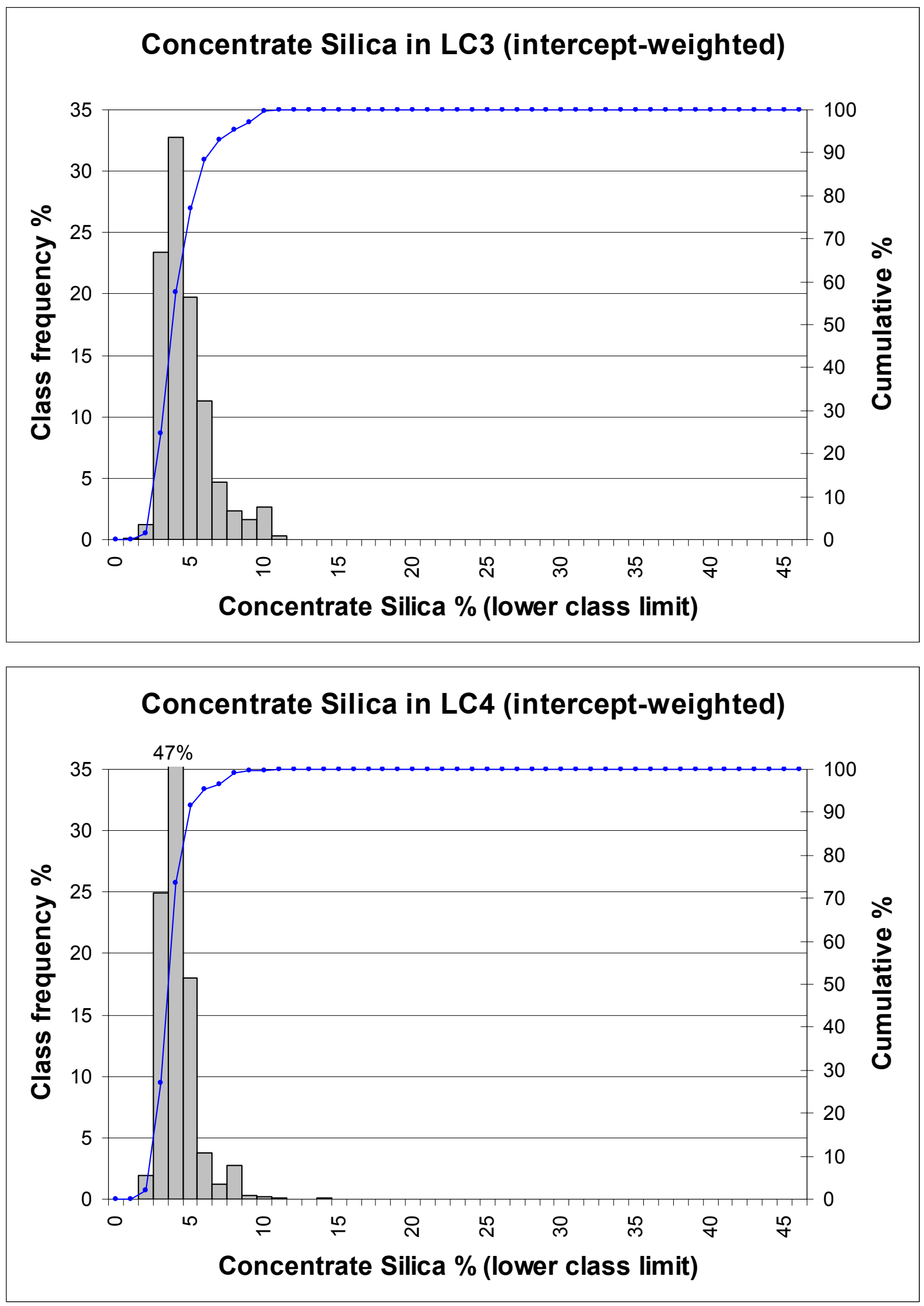

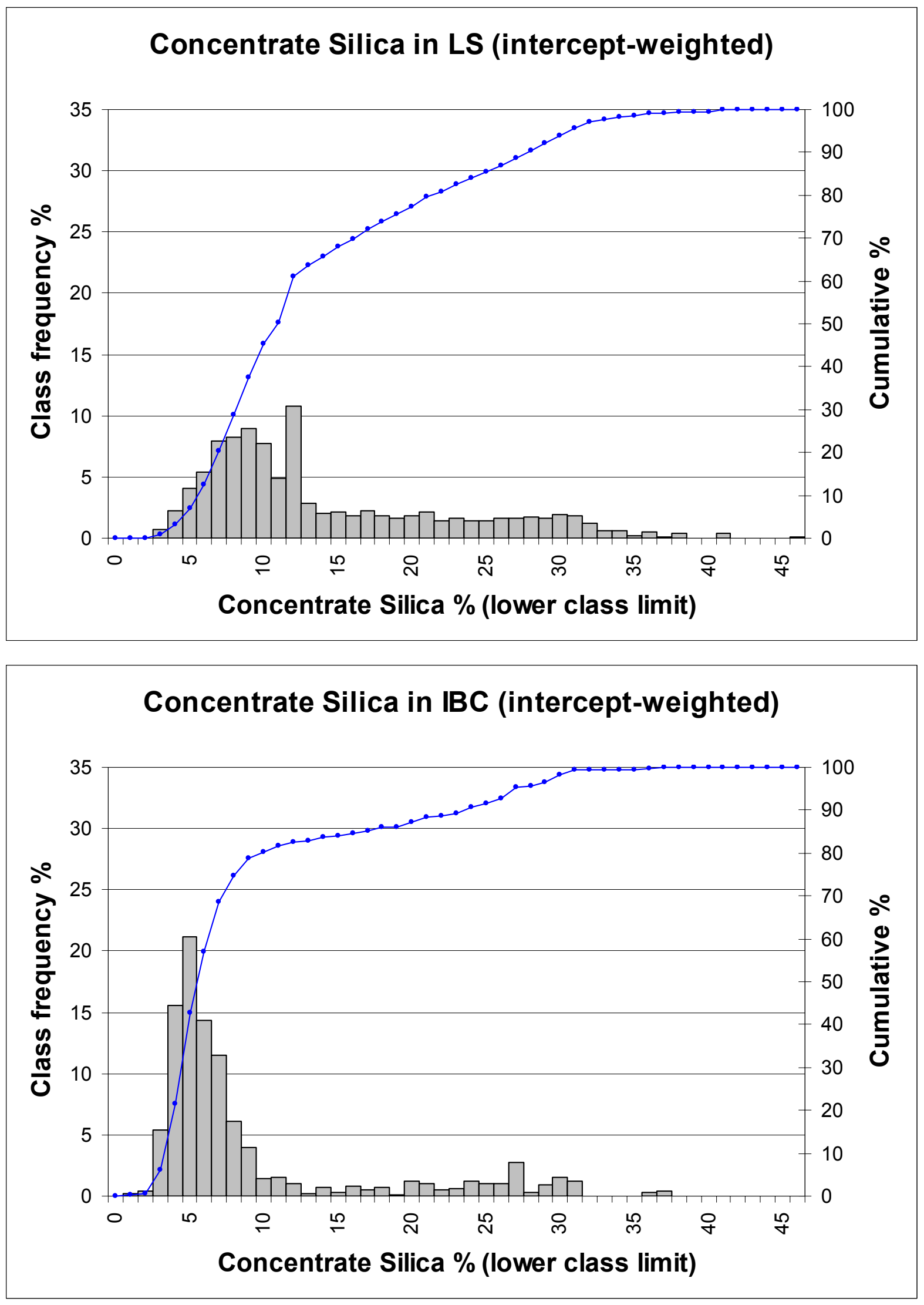

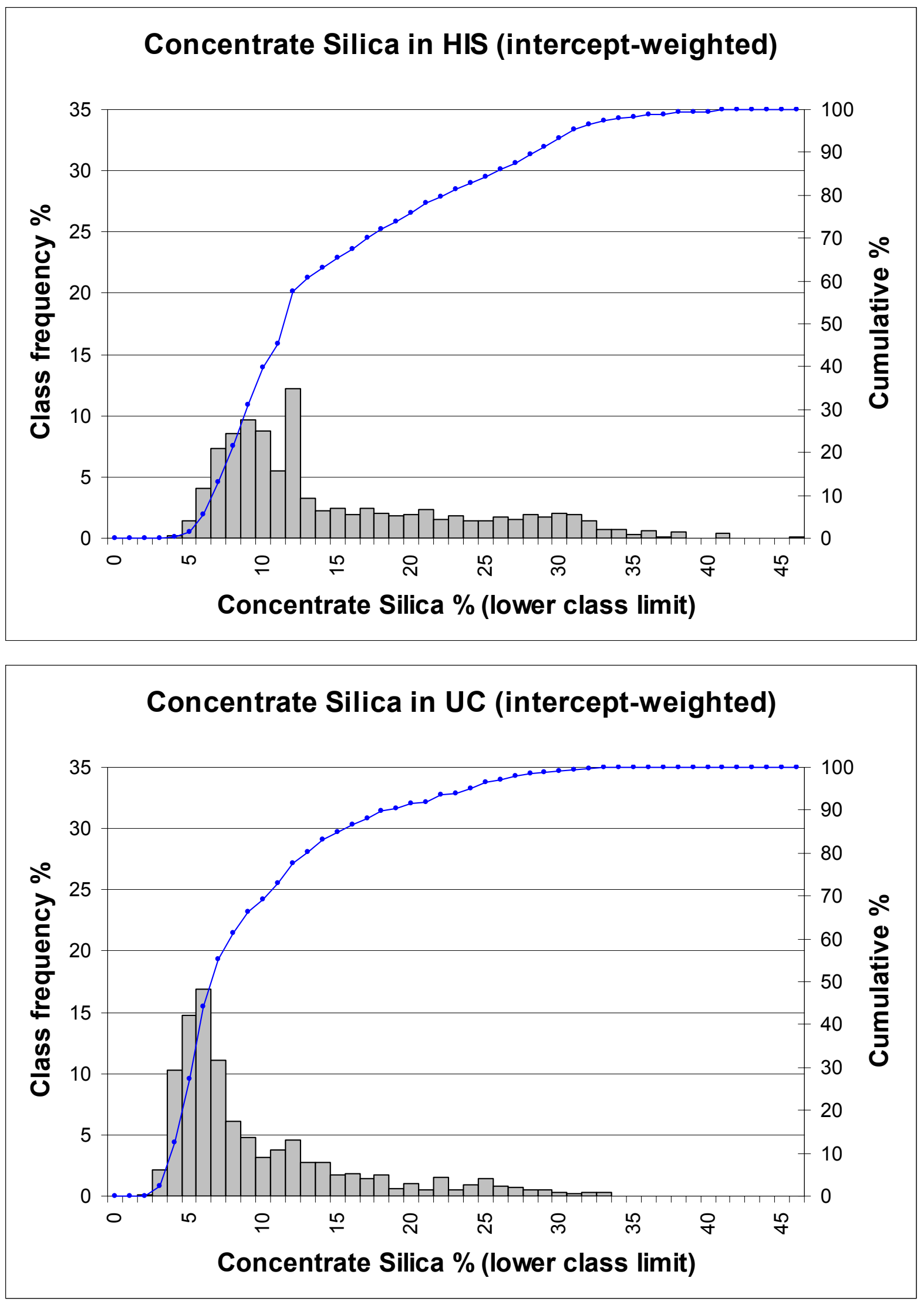